\title{
Heat integration and analysis of decarbonised IGCC sites
}

\author{
Kok Siew Ng, Yadira Lopez, Grant M. Campbell, Jhuma Sadhukhan*
}

Centre for Process Integration, School of Chemical Engineering and Analytical Science, The University of Manchester, P.O. Box 88, Manchester M60 1QD, UK

\begin{abstract}
A B S T R A C T
Integrated gasification combined cycle (IGCC) power generation systems have become of interest due to their high combined heat and power (CHP) generation efficiency and flexibility to include carbon capture and storage (CCS) in order to reduce $\mathrm{CO}_{2}$ emissions. However, IGCC's biggest challenge is its high cost of energy production. In this study, decarbonised coal IGCC sites integrated with CCS have been investigated for heat integration and economic value analyses. It is envisaged that the high energy production cost of an IGCC site can be offset by maximising site-wide heat recovery and thereby improving the cost of electricity (COE) of CHP generation. Strategies for designing high efficiency CHP networks have been proposed based on thermodynamic heuristics and pinch theory. Additionally, a comprehensive methodology to determine the COE from a process site has been developed. In this work, we have established thermodynamic and economic comparisons between IGCC sites with and without CCS and a trade-off between the degree of decarbonisation and the COE from the heat integrated IGCC sites. The results show that the COE from the heat integrated decarbonised IGCC sites is significantly lower compared to IGCC sites without heat integration making application of CCS in IGCC sites economically competitive.
\end{abstract}

() 2009 Published by Elsevier B.V. on behalf of The Institution of Chemical Engineers.

Keywords: Economic analysis; Heat integration; IGCC; CHP; CCS; Decarbonisation; Gasification; Energy efficiency

\section{Introduction}

Carbon dioxide is the main contributor to greenhouse gases and in $2004,40 \%$ of global $\mathrm{CO}_{2}$ emissions came from the energy industries (IEA, 2006). Fossil fuels such as coal are highly utilised in the energy industries to generate electricity, resulting in substantial $\mathrm{CO}_{2}$ emissions. Numerous actions have been initiated globally to protect the environment and ameliorate climate change by reducing emissions of greenhouse gases. The European Commission proposed to reduce $\mathrm{CO}_{2}$ emissions by $20 \%$ by 2020 , promote the use of renewable energy sources and endeavour to limit global temperature changes to a maximum of $2{ }^{\circ} \mathrm{C}$ relative to the pre-industrial level (European Commission, 2007). To this end, the European Union Emission Trading Scheme (EU ETS) started in 2005, in which Phase 1 of the scheme focuses on the reduction of $\mathrm{CO}_{2}$ emissions (European Commission, 2005).

The current world trend is demanding cleaner and energyefficient technologies to generate electricity. The integrated gasification combined cycle (IGCC) system is an excellent state-of-the-art technology. Studies have shown various promising advantages of IGCC compared to other power plants, such as air pollution mitigation and fuel flexibility (Ratafia-Brown et al., 2002; Shilling and Lee, 2003; Lee et al., 2007). IGCC often utilises coal as the feedstock to produce energy; coal is abundant and ubiquitous, and existing reserves can supply the world demand for over 250 years (Guha, 2001). However, the high carbon content in coal is causing a considerable increase in the amount of $\mathrm{CO}_{2}$ emitted to the environment. Hence, research aims to maximise the efficiency of a power plant and exploit carbon capture and storage (CCS), in order to reduce $\mathrm{CO}_{2}$ emissions to a minimum level. Various programmes and technologies have been proposed to achieve this mission. These include the Clean Coal Technology (CCT) (NMA, 2005) and CCS technology (IPCC, 2005; Rubin et al., 2007). The Clean Coal Technology (CCT), proposed by the U.S. Department of Energy and funded by both government and industries, aims to reduce the emission of $\mathrm{CO}_{2}$ and other pollutants produced by coal power plants. It is desired that a high efficiency coal power plant can be achieved with zero-emission. IGCC is one of the main projects in CCT. Meanwhile, CCS is recognised as "a potential greenhouse gas

\footnotetext{
* Corresponding author. Tel.: +44 161306 4396; fax: +44 1612367439.

E-mail addresses: Jhuma.Sadhukhan@manchester.ac.uk, jhumasadhukhan@gmail.com (J. Sadhukhan).

Received 20 January 2009; Received in revised form 1 August 2009; Accepted 6 August 2009

0263-8762/\$ - see front matter @ 2009 Published by Elsevier B.V. on behalf of The Institution of Chemical Engineers. doi:10.1016/j.cherd.2009.08.002
} 


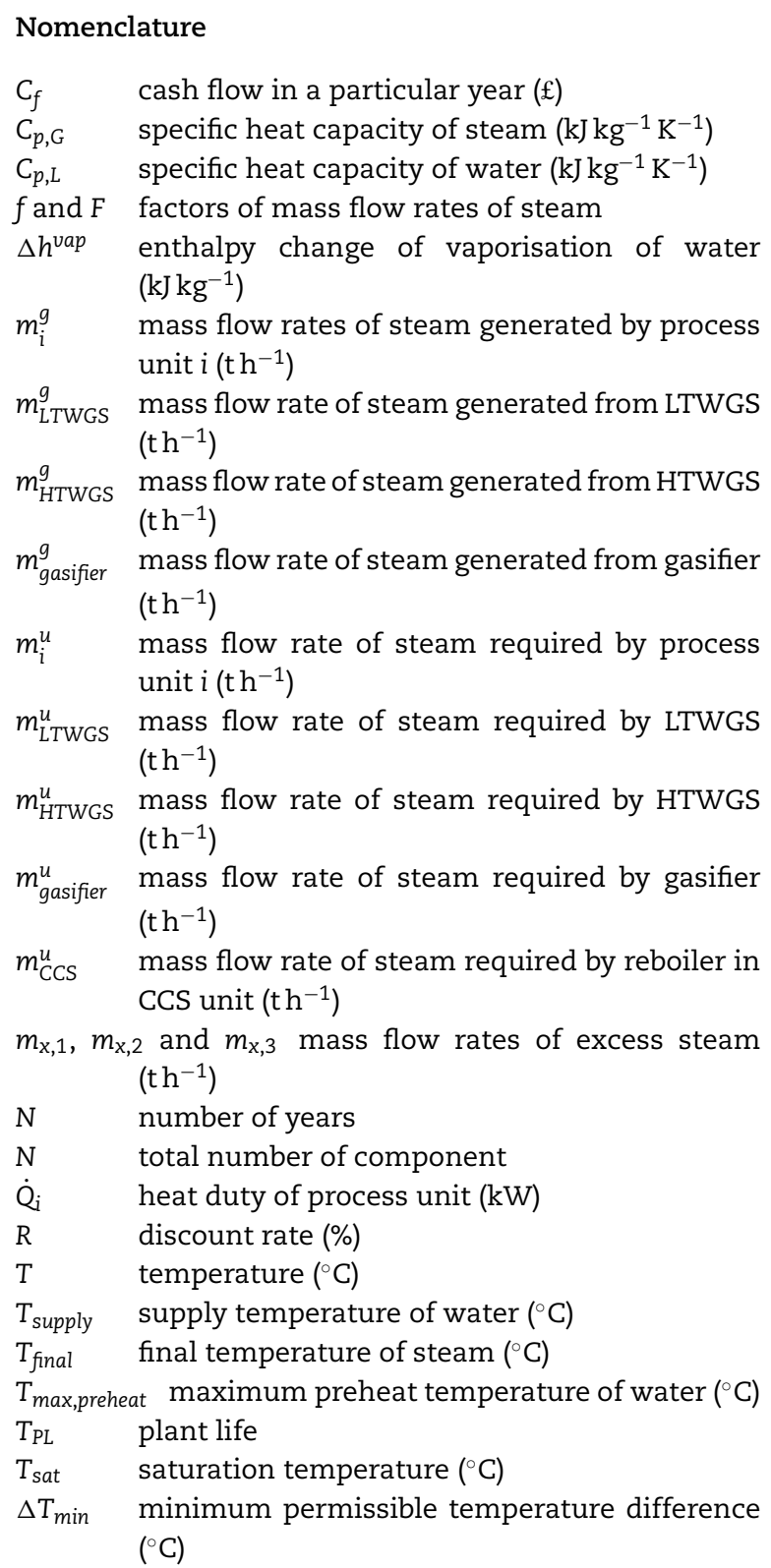

mitigation option for fossil fuel power plants" (Rubin et al., 2007). However, the inclusion of $\mathrm{CO}_{2}$ capture facilities into IGCC will incur an additional cost of approximately $25-36 \%$ to the capital cost, depending on the type of gasifier and feedstock (Ordorica-Garcia et al., 2006). Hence, a site should be designed to be "capture-ready" so that the expensive cost of retrofitting can be avoided (Bohm et al., 2007). In addition, inclusion of CCS technology can reduce the power generation from a site. Therefore, trade-offs between the degree of decarbonisation and the energy generation from a decarbonised site need to be analysed so that a reasonable cost of electricity (COE) can be attained, while reducing $\mathrm{CO}_{2}$ to an acceptable level. The major challenge of this work is to find systematic ways to achieve a cost effective promising performance for "capture-ready" coal IGCC sites. The objective of the current research is to investigate the impact of the degrees of freedom such as the extent of decarbonisation, on the costs of energy production from coal IGCC sites integrated with CCS technology.

The energetic analysis of a whole IGCC site "remains a complicated problem due to mutual influences of each pro- cess on their design and performance" (Vlaswinkel, 1992). There are many considerations in integrating an IGCC site, such as the integration among the air separation unit (ASU), gasifier and gas turbine, as well as the heat integration across a site, in order to enhance the overall efficiency of a plant. The integration of the ASU, gasifier and gas turbine enhances the power generation efficiency and reduces $\mathrm{NO}_{x}$ emissions. Heat integration of an IGCC site is imperative since it increases the profitability of the investment through energy saving (Linnhoff, 2000). Heat integration using pinch analysis provides a systematic approach for energy saving in processes and total sites (Linnhoff, 1998). Pinch analysis is used to achieve the minimum energy consumption, by means of composite curves (Linnhoff, 1998). Secondly, a methodology known as total site analysis has been developed to optimise a whole site as a single unit (Linnhoff, 1998, 2000). The optimisation of individual items of equipment is found to be impractical since the impact on other equipment is uncontrollable. In integrated or total site analysis, the challenge remains in decision making for individual processes which influences one way or the other, when linking them together by material and utility streams. This work aims at the development of a simulation framework for integrated design of capture ready IGCC plants, based in Aspen Plus. Aspen Plus is widely adopted in industry for process simulation purposes (Ordorica-Garcia et al., 2006; Kanniche and Bouallou, 2007; Lee et al., 2007). The unified framework created in this work captures the effects of individual process variability on the overall performance of a plant. The framework can be used to establish the heat and mass balance for an IGCC plant. Furthermore, in this work, the design of maximum heat recovery and steam turbine networks were consolidated using the various heat integration strategies highlighted above, adopted in specialised software, STAR developed for optimisation of steam turbine networks in the Centre for Process Integration at The University of Manchester.

A power plant must also be economically viable, while being environmentally benign and technically feasible. Carbon taxes are levied on the emission of $\mathrm{CO}_{2}$ to the atmosphere resulting from combustion of fossil fuel (Carbon Tax Center, 2008). Carbon tax has been implemented in many countries such as Finland, Denmark, Norway, Sweden and New Zealand (BCSEA, 2007; Carbon Tax Center, 2008). However, the UK only introduced the climate change levy in 2001, but not carbon tax (Carbon Tax Center, 2008). The climate change levy in the UK aims to promote energy efficiency in the industrial sector and reduce greenhouse gas emissions (DEFRA, 2007). There have been appeals to replace the climate change levy by carbon tax, which is a more direct way to reduce $\mathrm{CO}_{2}$ emissions (Carbon Tax Center, 2008). A more profound means to check on $\mathrm{CO}_{2}$ emissions is based on the EU ETS emission trading or capand-trade scheme. A number of $\mathrm{CO}_{2}$ emission certificates or EU Allowances (EUA), of which a certificate signifies allowance of one tonne of $\mathrm{CO}_{2}$ emission for a year, are allocated to companies such as refineries (Wagner and Uhrig-Homburg, 2007). These certificates can be sold or purchased at the discretion of the company, depending on the economic viability for capturing and abatement of $\mathrm{CO}_{2}$

In the current work, a comprehensive methodology to predict COE from an IGCC site using the above factors is presented. Process simulation-based approaches using Aspen Plus have been developed. The paper is structured as follows. In Section 2, a validation of the results from process simulation of coal IGCC sites against the results found in literature 


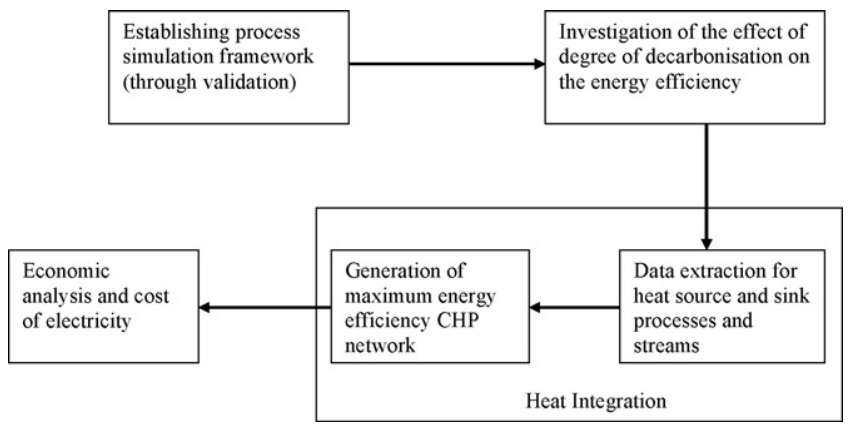

Fig. 1 - Methodology for heat integration and analysis of IGCC site.

is presented. Next, a comprehensive methodology for performing heat integration on an IGCC site has been discussed. Case studies considering different degrees of $\mathrm{CO}_{2}$ are detailed in Section 3. The steam balance, preheat temperatures and power generation for different cases are established. Subsequently, the economic evaluation of each case where the COE is determined is presented in Section 3. The work is summarised in Section 4.

\section{Methodology}

The strategy adopted for the heat integration and analysis for decarbonising IGCC sites is summarised in Fig. 1. The various steps for establishing the process simulation framework, investigation of the degree of decarbonisation of an IGCC site, heat integration and economic analysis and cost of electricity are discussed in detail in the following subsections.

\subsection{Establishing a process simulation framework for a coal IGCC site}

Fig. 2 presents the IGCC flow sheet used for validating and establishing the simulation framework. Gasification is a process that converts carbonaceous materials, such as coal, petroleum, or biomass, into carbon monoxide and hydrogen by reacting the raw material at high temperatures with a controlled amount of oxygen (i.e. partial oxidation) and/or steam. In this case, the feed (coal) together with oxygen $\left(\mathrm{O}_{2}\right)$ are preheated and fed to the gasifier. The gasifier selected in this study is an oxygen-blown entrained flow gasifier with slurry feedstock and heat recovery design. Such gasifiers are available from GE (formerly Texaco) and E-Gas. Another design of gasifier consists of water quench system where syngas is directly cooled with cold water (Phillips, 2006). The quench gasifier is not considered in this study since the sensible heat from the hot syngas can be used to generate high-pressure steam, hence enhanced power. However, the enhanced power generation is associated with higher capital investment and maintenance of entrained flow gasifiers. Steam is added so that the operating temperature of $1300^{\circ} \mathrm{C}$ in the gasifier is reached. This is to initiate the reaction and also to atomise the high viscosity reaction mixture (Hara et al., 2003). The steam also helps to moderate the temperature in the gasifier because the reaction between the steam and carbon is endothermic (DTI, 1998). The main reactions occurring within gasification are partial oxidation steam reforming and water-gas shift, providing an overall exothermic performance. The resulting gas mixture is called synthesis gas or syngas, which consists mainly of $\mathrm{CO}$ and $\mathrm{H}_{2}$ and is itself a fuel. The hot syngas which flows out from the gasifier contains very high heat and the

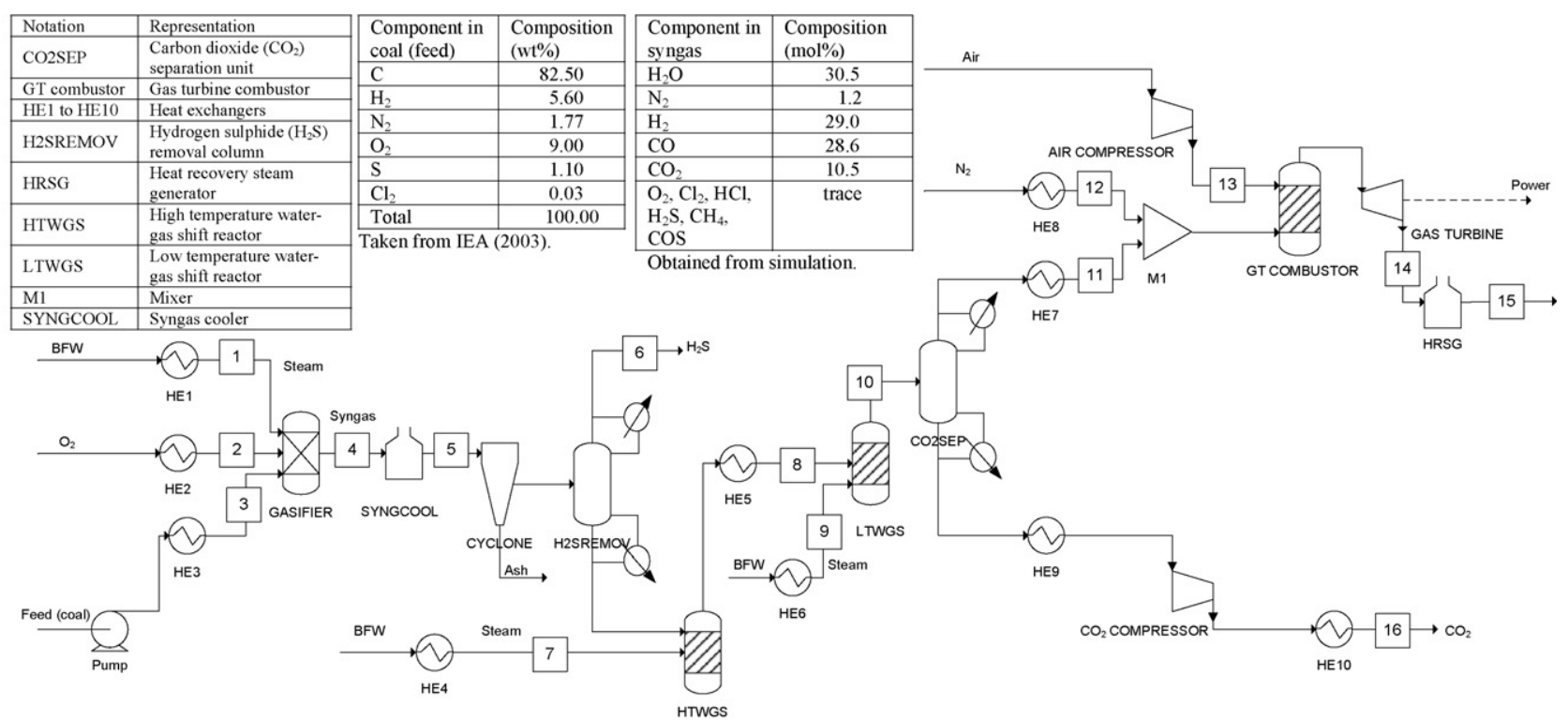

\begin{tabular}{|c|c|c|c|c|c|c|c|c|}
\hline Stream no. & 1 & 2 & 3 & 4 & 5 & 6 & 7 & 8 \\
\hline Mass flow rate $\left(\mathrm{t} \mathrm{h}^{\mathrm{T}}\right)^{*}$ & 400,$0 ; 400,0$ & $252.8 ; 262.0$ & $283.7 ; 287.6$ & $936.5 ; 949.6$ & $936.5 ; 949.6$ & $2.9 ; 2.9$ & $50.0 ; 80.0$ & $983.6 ; 1026.7$ \\
\hline Temperature $\left({ }^{\circ} \mathrm{C}\right)$ & 750 & 730 & 730 & 1300 & 450 & 450 & 450 & 250 \\
\hline Pressure (bar) & 50 & 1 & 55 & 65 & 60 & 60 & 1 & 55 \\
\hline Stream no. & 9 & 10 & 11 & 12 & 13 & 14 & 15 & 16 \\
\hline Mass flow rate $\left(\mathrm{t} \mathrm{h}^{\mathrm{p}}\right)$ & $25.0 ; 40.0$ & $1008.6 ; 1066.7$ & $265.9 ; 1066.7$ & $770.4,0.0$ & $1781.6 ; 1820.7$ & $2817.9 ; 2823.6$ & $2747.5 ; 2823.6$ & $742.7 ; 0.0$ \\
\hline Temperature $\left({ }^{\circ} \mathrm{C}\right)$ & 250 & 250 & 250 & 250 & 681 & 548 & 100 & 30 \\
\hline Pressure (bar) & 1 & 55 & 55 & 55 & 55 & 2 & 1 & 80 \\
\hline
\end{tabular}

* The mass of flows rate is stated in the form of mass flow rate for set (a) (with decarbonisation) ; mass flow rate for set (b) (without decarbonisation). 
Table 1 - Wobbe Index validation for cases with and without decarbonisation.

\begin{tabular}{|c|c|c|c|c|c|}
\hline \multirow[t]{2}{*}{ Component } & \multirow[t]{2}{*}{$\mathrm{HHV}$ at $25^{\circ} \mathrm{C}\left(\mathrm{MJ} \mathrm{kg}^{-1}\right)$} & \multicolumn{2}{|c|}{ Reference case } & \multicolumn{2}{|c|}{ Simulation case } \\
\hline & & Mole fraction & $\mathrm{HHV} \times$ mole fraction & Mole fraction & $\mathrm{HHV} \times$ mole fraction \\
\hline \multicolumn{6}{|c|}{ Case with decarbonisation (set (a)) } \\
\hline $\mathrm{H}_{2}$ & 141.9 & 0.4 & 56.76 & 0.419 & 59.39 \\
\hline $\mathrm{CO}$ & 10.9 & 0.2 & 2.18 & 0.013 & 0.14 \\
\hline \multirow[t]{3}{*}{$\mathrm{CH}_{4}$} & 55.5 & 0.1 & 5.55 & $1.27 \times 10^{-4}$ & 0.01 \\
\hline & & Sum & 64.49 & Sum & 59.54 \\
\hline & & Wobbe Index & 10.30 & Wobbe Index & 9.51 \\
\hline \multicolumn{6}{|c|}{ Case without decarbonisation (set (b)) } \\
\hline $\mathrm{H}_{2}$ & 141.9 & 0.4 & 56.76 & 0.497 & 70.52 \\
\hline $\mathrm{CO}$ & 10.9 & 0.2 & 2.18 & 0.013 & 0.14 \\
\hline \multirow[t]{3}{*}{$\mathrm{CH}_{4}$} & 55.5 & 0.1 & 5.55 & $1.59 \times 10^{-4}$ & 0.01 \\
\hline & & Sum & 64.49 & Sum & 70.67 \\
\hline & & Wobbe Index & 10.30 & Wobbe Index & 11.29 \\
\hline
\end{tabular}

heat can be recovered to superheat steam in syngas coolers, SYNGCOOL in Fig. 2. After removal of ash and unwanted sulphur components from syngas in the cyclone and $\mathrm{H}_{2} \mathrm{~S}$ removal unit, respectively, cleaner syngas is supplied to the high and low temperature water-gas shift reactors, HTWGS and LTWGS, respectively, with the purpose of achieving better conversion of $\mathrm{CO}$ to $\mathrm{H}_{2}$ and $\mathrm{CO}_{2}$ via a water-gas shift reaction. Steam is also used for the water-gas shift conversion at $450^{\circ} \mathrm{C}$ and $250^{\circ} \mathrm{C}$ in HTWGS and LTWGS, respectively. The syngas, which is rich in $\mathrm{H}_{2}$ and $\mathrm{CO}_{2}$, is then transferred to the carbon capture and storage (CCS) unit to separate $\mathrm{CO}_{2}$, in a pre-combustion decarbonisation route (Lou et al., 2008). The CCS unit mainly comprises a separator (CO2SEP) and $\mathrm{CO}_{2}$ compressor. The separator is made up of an absorber column and a stripper column (or other technologies), where MDEA (methyldiethanolamine) is used as solvent (or other types of solvent) (Kanniche and Bouallou, 2007). The CCS unit, which is simplified as a $\mathrm{CO}_{2}$ separator in Fig. 2, has been studied in detail elsewhere (Lou et al., 2008). A CO 2 compressor is used to compress the $\mathrm{CO}_{2}$ gas to a supercritical condition for transportation, i.e. to approximately 80 bar (Williams et al., 2007). The decarbonised $\mathrm{H}_{2}$-rich syngas and air in excess (also nitrogen as an inert gas from the air separation unit) are transferred to the gas turbine to generate power. The combustion reactions take place in the GT combustor, while the expander is used to generate power. The gas turbine exhaust has very high heat content and it is sent to the heat recovery steam generator (HRSG) that produces saturated steam. Besides HRSG and SYNGCOOL, other heat recovery units include exothermic reaction heats from the gasifier, HTWGS and LTWGS.

The thermodynamic property chosen for the simulation is non-random two liquid (NRTL) model. This is an activity coefficient model that can be used to describe the vapour-liquid equilibrium. The gasifier is modelled using the Gibb's free energy minimisation method, thus a Gibbs reactor (RGibbs) has been chosen (Lee et al., 2007). The equilibrium reactors are selected for modelling the water-gas shift reactors and GT combustor. This is to perform the stoichiometric calculations on the chemical and phase equilibria simultaneously.

The results of simulation were validated for two sets: (a) IGCC site with decarbonisation; and (b) IGCC site without decarbonisation. The validation of results involves a comparison of the net useful energy generated from the site. For sets (a) and (b), the corresponding values of the net heat generation were obtained from Cases D.1 and C.2, respectively, in IEA (2003). The mass flow rates of feed are $283.7 \mathrm{t} \mathrm{h}^{-1}$ for set (a) and
$287.6 \mathrm{th}^{-1}$ for set (b), respectively, as obtained from IEA (2003) Table B.6.1. In establishing the simulation framework this way, the following process constraints were considered.

Wobbe Index (WI) of gas turbines: $\mathrm{N}_{2}$ is added to the GT combustor to reduce the temperature and hence $\mathrm{NO}_{x}$ emission (Williams et al., 2007). It also acts as an inert gas to ensure that the combustion takes place in a safe manner and does not cause damage to the equipment (Nag et al., 2007). The safe region is specified by the WI of the syngas in the combustor. WI indicates the heating value of a feed gas. Using this, the heat flow from the syngas in the gas turbine can be monitored and controlled to a consistent range (Driftmeier, 2004). It is suggested that the WI should not exceed $\pm 10 \%$ compared to the base case (Shah et al., 2005). This can be done by varying the flow rate of $\mathrm{N}_{2}$. For the case without decarbonisation, $\mathrm{N}_{2}$ is not needed since there is a large amount of $\mathrm{CO}_{2}$ which acts as the inert gas to reduce the $\mathrm{NO}_{x}$ emission. The compositions of the combustible components such as $\mathrm{H}_{2}, \mathrm{CO}$ and $\mathrm{CH}_{4}$ in the syngas were taken into account for verifying the WI with respect to the base case. The calculation involved is a proportional expression, as shown in Eq. (1).

\section{WI(simulation)}

$$
\begin{aligned}
=\frac{\sum_{c=1}^{N} \mathrm{HHV} \times \text { mole fraction from simulation case }}{\sum_{c=1}^{N} \mathrm{HHV} \times \text { mole fraction from reference case }} \\
\times \mathrm{WI}(\text { reference })
\end{aligned}
$$

The higher heating values (HHV) are given by Perry and Green (1997). WI and the reference case components' mole fractions were obtained from Shah et al. (2005). The WIs of the reference case and the simulation case were compared to ensure that the limit of WI is within $\pm 10 \%$. Table 1 shows the validation results of WI for the cases with decarbonisation (set (a)) and without decarbonisation (set (b)), respectively.

Heat is generated on the site by the syngas cooler, HRSG and gas turbine combustor, while heat is consumed by HE1 and power by air compressor and $\mathrm{CO}_{2}$ compressor. The net useful energy is the difference between the combined energy generation and consumption. The results with and without decarbonisation are shown in Table 2 .

The literature (IEA, 2003) gives the net useful energy of $730 \mathrm{MW}$ and $861 \mathrm{MW}$ for the case with decarbonisation and without decarbonisation, respectively. Thus Table 2 shows good agreement of the results obtained from the simulation 
Table 2 - The estimation of net useful energy generated from the site.

\begin{tabular}{|c|c|c|c|}
\hline \multirow[t]{2}{*}{ Process unit } & \multirow{2}{*}{$\begin{array}{l}\text { Generation (G)/ } \\
\text { consumption (C) }\end{array}$} & \multicolumn{2}{|c|}{ Heat duty/power (MW) } \\
\hline & & $\begin{array}{c}\text { Case with decarbonisation } \\
\text { (set (a)) }\end{array}$ & $\begin{array}{l}\text { Case without decarbonisation } \\
\text { (set (b)) }\end{array}$ \\
\hline SYNGCOOL & G & 421.0 & 422.2 \\
\hline HRSG & G & 432.6 & 505.9 \\
\hline Gas turbine & G & 828.9 & 804.0 \\
\hline HE1 & C & 533.8 & 533.8 \\
\hline Air compressor & C & 345.1 & 352.7 \\
\hline $\mathrm{CO}_{2}$ compressor & C & 71.8 & - \\
\hline Net useful energy & & 731.8 & 845.6 \\
\hline
\end{tabular}

Table 3 - The mass balance of air around ASU, gasifier and gas turbine for each case with different degrees of decarbonisation.

\begin{tabular}{lccr} 
Mass flow rate & \multicolumn{2}{c}{ Mass flow rate $\left(\mathrm{t} \mathrm{h}^{-1}\right)$} \\
\cline { 2 - 4 } & 100\% decarbonisation & 60\% decarbonisation & 0\% decarbonisation \\
\hline Air into ASU & 1028.7 & 1028.7 & 778.7 \\
Air into gas turbine & 1775.8 & 1775.8 & 1775.8 \\
$\mathrm{~N}_{2}$ from ASU into gas turbine & 750.0 & 750.0 & 500.0 \\
$\mathrm{O}_{2}$ from ASU into gasifier & 278.7 & 278.7 & 278.7
\end{tabular}

with the published work, with a discrepancy of less than $2 \%$ compared to the values given in the literature.

An air separation unit (ASU) is used to separate $\mathrm{O}_{2}$ and $\mathrm{N}_{2}$ in the air. $\mathrm{O}_{2}$ from ASU is fed to the gasifier while $\mathrm{N}_{2}$ from ASU is sent to the gas turbine. Excess air is also required in the gas turbine. The flows of air $\left(\mathrm{O}_{2}\right.$ and $\left.\mathrm{N}_{2}\right)$ into ASU, gasifier and gas turbine were integrated. The air required in the ASU and the amount of $\mathrm{N}_{2}$ to be used in the gas turbine to meet the Wobbe Index were determined using Eq. (1), Table 1 and a generic mass balance of air distributed among the three process units.

\subsection{Investigation of degree of decarbonisation of an IGCC site}

Three case studies with different degrees of decarbonisation were carried out in this study: $100 \%$ decarbonisation, $60 \%$ decarbonisation and no decarbonisation. While $100 \%$ decarbonisation is optimistic to achieve in practice, no decarbonisation is environmentally unacceptable, $60 \%$ decarbonisation of an IGCC site is a practical compromise. Nevertheless, it is useful to analyse how the heat integration, economic analysis and cost of electricity may evolve over an entire range of decarbonisation. The mass balance around the integrated system of ASU, gasifier and gas turbine for the three case studies is summarised in Table 3. It can be noted that the mass flow rates of air and its components for the cases with $100 \%$ and $60 \%$ decarbonisation as shown in Table 3 are the same. This is because the range of WI has been constrained to $\pm 10 \%$ compared to the base case. The WIs for these two cases fall within this range, and therefore there is no need to adjust $m_{N_{2}}$. Lower degree of decarbonisation means that more $\mathrm{CO}_{2}$ and less $\mathrm{N}_{2}$ are transferred to the gas turbine.

Next, the heat integration strategies of these sites were established. Some heat integration strategies are common to all IGCC schemes with different degrees of decarbonisation. This is because the steam required by LTWGS, HTWGS and gasifier is the same regardless of the degree of decarbonisation. The steam requirement by the carbon capture and storage unit (CCS) varies depending on the degree of decarbonisation. Accordingly maximum heat recovery and power generation schemes diverge. These are discussed in the following section.

\subsection{Heat integration of coal IGCC site}

Heat integration on the total site, based on the maximum steam recovery, was carried out to enhance the combined heat and power generation or cogeneration (CHP) from a site. The steam generated on the site is first used to fulfil the heat requirements of the process units including preheating of

Table 4 - Heat recovery and operating temperature level/range of process units, steam flow rate and temperature of steam required by the process units.

\begin{tabular}{lcccc} 
Unit & $\begin{array}{c}\text { Heat recovery } \\
(\mathrm{MW})\end{array}$ & $\begin{array}{c}\text { Operating temperature } \\
\text { level/range }\end{array}$ & $\begin{array}{c}\text { Steam flow rate } \\
\text { requirement }\left(\mathrm{th}^{-1}\right)\end{array}$ & $\begin{array}{c}\text { Temperature of } \\
\text { steam required } \\
\left({ }^{\circ} \mathrm{C}\right)\end{array}$ \\
\hline LTWGS & 47.7 & $250^{\circ} \mathrm{C}$ & $m_{\text {LTWGS }}^{u}=25.0$ & 264 \\
HTWGS & 83.6 & $450^{\circ} \mathrm{C}$ & $m_{\text {HTWG }}^{u}=50.0$ & 430 \\
Gasifier & 3346.4 & $1300^{\circ} \mathrm{C}$ & $m_{\text {gasifier }}^{u}=400.0$ & 750 \\
HRSG & 404.3 & $546-100^{\circ} \mathrm{C}$ & - & - \\
SYNGCOOL & 404.4 & $1300-450^{\circ} \mathrm{C}$ & - & - \\
CCS & - & - & $m_{\text {CCS }}^{u}=1230.4^{\text {a }}$ & 120 \\
\hline
\end{tabular}

${ }^{a}$ This is the steam flow rate required at $100 \%$ decarbonisation condition. The steam flow rate in the CCS unit depends on the degree of decarbonisation. 
feed streams to reactors (e.g. gasifier) in order to improve the heat availability to the reactors. Steam turbines are utilised to downgrade steam available at high pressure to low pressure for the purpose of power generation. The excess steam from the site utilised in power generation and boiler feed water (BFW) is returned to steam generation. The heat integration exercise comprised of the following steps.

\subsubsection{Data extraction}

Data such as heat availability or recovery and temperatures of the process units were extracted from the flow sheet simulation results (Fig. 2) in order to carry out the heat integration analysis. This procedure is vital to ensure that there is no missed opportunity for heat recovery on the site which may eventually incur economic losses (Smith, 2005).

There are five process units in the flow sheet in Fig. 2 that are potentially useful for heat recovery from the site. These are the low temperature water-gas shift reactor (LTWGS), high temperature water-gas shift reactor (HTWGS), gasifier, heat recovery steam generator (HRSG) of the gas turbine and syngas cooler (SYNGCOOL). Table 4 shows the heat recoveries and temperatures of each process unit extracted from the flow sheet simulation results in Fig. 2. The data such as mass flow rates and target temperatures of the steam used in the reaction processes were extracted. Many of these temperatures of the inlet streams to the process units can be regarded as soft temperatures, meaning that there is some flexibility to change this temperature (Smith, 2005).

The pressure of the steam generated was assumed to be at 50 bar (high-pressure (HP) steam) and the saturation temperature of the HP steam is $264^{\circ} \mathrm{C}$. The steam injected into the LTWGS was therefore taken at $264^{\circ} \mathrm{C}$ instead of the reaction temperature of $250^{\circ} \mathrm{C}$. The temperature of the steam required by HTWGS was set to $430^{\circ} \mathrm{C}$, instead of its operating temperature of $450^{\circ} \mathrm{C}$ (low temperature superheated steam, by assuming $\Delta \mathrm{T}_{\min }$ of $20^{\circ} \mathrm{C}$ ). The temperature of the steam to the gasifier was set to the maximum temperature of $750^{\circ} \mathrm{C}$, rather than the gasifier operating temperature of $1300^{\circ} \mathrm{C}$ that can be attained for the superheated steam. There are three levels of steam requirement on the site, i.e. $264^{\circ} \mathrm{C}$ (saturated steam), $430^{\circ} \mathrm{C}$ and $750^{\circ} \mathrm{C}$ (low and high-temperature superheated steam, respectively).

\subsubsection{Sequential arrangement of process units for designing the CHP networks}

The core of a heat integration analysis is to devise the CHP networks. The determination of the tasks of the process units, e.g. preheating BFW, generating steam and superheating steam, is contemplated in order to arrive at the final designs. The heat from the processes is very valuable and hence it should be utilised optimally so that the greatest savings in the energy costs can be achieved.

In the cogeneration system, the highest available pressure of the steam generation should be considered and prioritised (Tsatsaronis, 1993). This is because higher pressure steam can be converted into lower pressure steam or BFW where necessary, by using a steam turbine. For deriving optimal CHP network, low levels of heat recovery and temperature should be assigned to low level steam generation tasks, and vice versa. This heuristic arising from the thermodynamic matching rule states that the hot streams and the cold streams are to be matched consecutively in a decreasing order of their average stream temperatures (Liu, 1987). Another similar heuristic known as the hottest/highest matching heuristic, proposed by Ponton and Donaldson (1974), states that "the hot stream having the highest supply temperature should be matched with the cold stream having the highest target temperature". Therefore, it was decided to avail the exothermic heat of LTWGS and HTWGS to preheat the BFW (low level heat recovery and low level steam generation task). The process units with medium heat recoveries, i.e. HRSG and SYNGCOOL, should be utilised for saturating or superheating the steam. Unquestionably, the heat extraction from the process units with the highest heat recoveries and temperatures, i.e. the exothermic heat of the gasifier, should be used to superheat the steam at the highest temperature, by applying the same rationale.

HRSG is preferable than SYNGCOOL for generating the saturated steam because it can generate approximately double the amount of steam. Although HRSG and SYNGCOOL have similar heat duties, SYNGCOOL exhibits a higher temperature level and range than HRSG, i.e. $1300-450^{\circ} \mathrm{C}$, compared to $546-100^{\circ} \mathrm{C}$, respectively, as presented in Table 4 . Hence, it is appropriate to use HRSG before SYNGCOOL to generate or superheat steam. Thus SYNGCOOL is more suitable for superheating the steam to $750^{\circ} \mathrm{C}$ while HRSG is desirable for either saturating the steam to $264^{\circ} \mathrm{C}$ or superheating the steam to $430^{\circ} \mathrm{C}$. Therefore, two case studies can arise, with either saturation or superheating of the steam using HRSG, as follows.

Case A.1: Superheated steam at $430^{\circ} \mathrm{C}$ is generated using HRSG.

Case A.2: Saturated steam at $264^{\circ} \mathrm{C}$ is generated using HRSG.

In both cases, after the HRSG, SYNGCOOL is used to superheat steam to $750^{\circ} \mathrm{C}$ as discussed above. The gasifier exothermic heat can be used independently to superheat the steam to $750^{\circ} \mathrm{C}$ due to its more than 8 times higher exothermic heat than any other process unit on the site. The HP steam generated at 50 bar and $750^{\circ} \mathrm{C}$ by the gasifier exothermic heat is more than sufficient for supplying steam for its own use (gasification reactions). The excess steam produced can further be used to provide heat and power by expanding to lower pressure and lower temperature steam or BFW through the steam turbines to other places. Research is into the development of ultra steam turbine and high temperature reheat steam turbines with new high temperature materials to expand the limits for steam parameters, i.e. a temperature range of $600-760^{\circ} \mathrm{C}$ for steam turbines has been reported (Holcomb et al., 2003; Quinkertz et al., 2008). A higher pressure steam turbine can also be assumed, leading to increased power generation from supercritical steam turbines. As can be noted, increased pressure than increased temperature has much more profound effect on the power generation from steam turbines. However, such steam turbines and the property data of supercritical steam are at an early stage of development, and yet to be implemented in process simulation software. Hence, higher pressure was not assumed to avoid any ambiguity between the amount of power generation predicted and pressure assumed.

Steam turbines are positioned to reduce the pressure or "downgrade" steam. Valuable power is extracted at the same time when steam is extracted at lower temperature and pressure, thus exploiting CHP generation from the site.

\subsubsection{Maximising heat recovery via pinch analysis}

HRSG and SYNGCOOL operate over a temperature range to extract heat into steam from the gas turbine exhaust gas and 


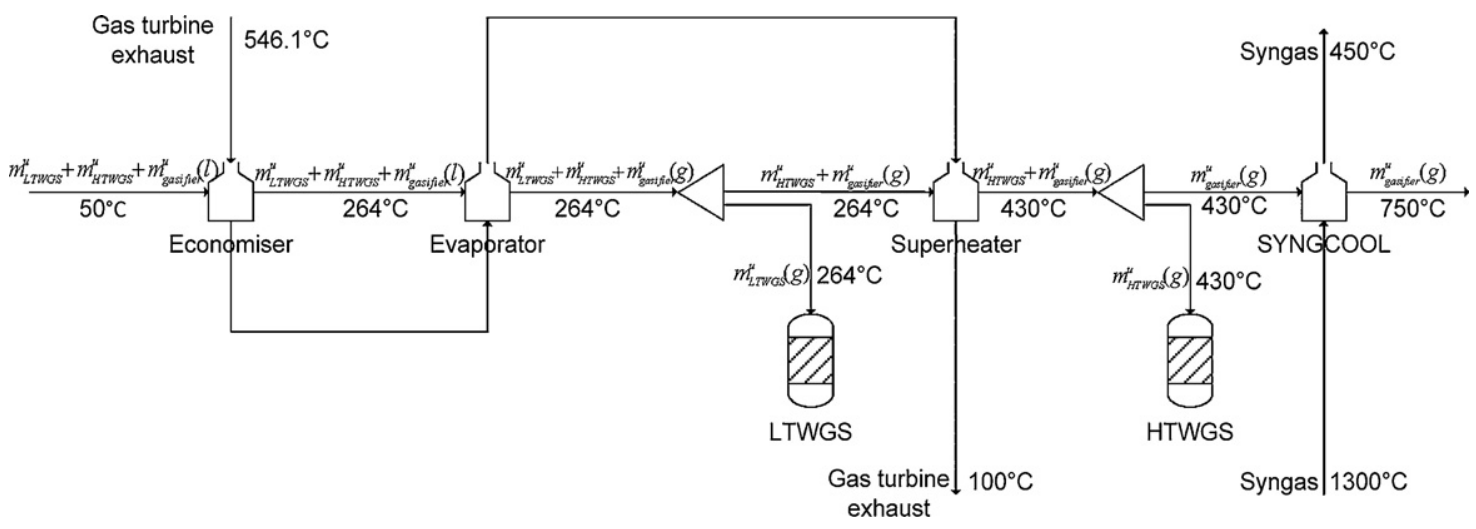

Fig. 3 - A flow diagram showing the generation of steam in the boilers (HRSG and SYNGCOOL) and the distribution of steam to the process units. Economiser, evaporator and superheater are components of HRSG. $(\mathrm{l})$ and $(\mathrm{g})$ denote the water and vapour states, respectively. This diagram is used for both Case A.1 and Case A.2.

Table 5 - Three levels of steam generation: heating of BFW, saturation and superheating of steam in the HRSG.

\begin{tabular}{lccll} 
Segment & Initial temperature $\left({ }^{\circ} \mathrm{C}\right)$ & Final temperature $\left({ }^{\circ} \mathrm{C}\right)$ & \multicolumn{2}{c}{ Mass flow rate of steam $\left(\mathrm{t} \mathrm{h}^{-1}\right)$} \\
\hline 1 & 50 & 264 & $\left(m_{\text {LTWGS }}^{u}+m_{\text {HTWGS }}^{u}+m_{\text {gasifier }}^{u}\right)$ & 475 \\
2 & 264 & 264 & $\left(m_{\text {LTWGS }}^{u}+m_{\text {HTWGS }}^{u}+m_{\text {gasifier }}^{u}\right)$ & 475 \\
3 & 264 & 430 & $\left(m_{\text {HTWG }}^{u}+m_{\text {gasifier }}^{u}\right)$ & 450 \\
\hline
\end{tabular}

syngas, respectively (Table 4). Hence, maximum heat recovery or steam generation from these two units can be achieved by applying pinch analysis. Pinch analysis ensures feasible heat integration between hot and cold streams (gas turbine exhaust gas-syngas and steam generation, respectively) and no temperature cross-over between them.

The mass flow rates of steam which can be generated from HRSG and SYNGCOOL were determined for Cases A.1 and A.2, by applying the principle of the minimum temperature driving force between hot and cold composite curves. $A \Delta T_{\text {min }}$ of $20^{\circ} \mathrm{C}$ was assumed for all the heat exchanger equipment. This is a typical experience-based value applied for steam against process streams, and also to achieve good heat transfer coefficient of condensing and evaporation, as suggested by Linnhoff (1998). The inlet temperature of the cold stream (BFW) to HRSG was assumed to be $50^{\circ} \mathrm{C}$ as a preliminary estimation, which was corrected iteratively while carrying out detailed mass balance. The mass flow rates of steam required by LTWGS $\left(m_{\text {LTWGS }}^{u}\right)$, HTWGS ( $\left.m_{\text {HTWGS }}^{u}\right)$ and gasifier $\left(m_{\text {gasifier }}^{u}\right)$ were taken as the basis (Table 4 ) to predict how much steam in excess could be generated from the HRSG. These amounts of steam required by LTWGS, HTWGS and gasifier are fixed regardless of the degree of decarbonisation. The steam requirement of the carbon capture and storage (CCS) unit $\left(m_{C C S}^{u}\right)$ was not taken as the basis (Table 4) since it varies depending on the degree of decarbonisation. Fig. 3 illustrates the steam generation in the boilers and distribution among the process units, for both the Cases A.1 and A.2, as discussed in the previous section.

Economiser, evaporator and superheater are components of the boilers (HRSG) for carrying out three different tasks where economiser heats BFW up to the saturation temperature, evaporator undertakes the saturation to steam from saturated BFW, and superheater superheats the steam from the saturation temperature of $264^{\circ} \mathrm{C}$ to the superheating temperature of $430^{\circ} \mathrm{C}$. Table 5 presents the three levels of steam generation from the HRSG for Case A.1 with $100 \%$ decarbonisation.

Once the hot and cold composite curves of HRSG are constructed using the mass flow rates of steam provided in Tables 4 and 5, as shown in Fig. 4(a), it results in a higher temperature driving force than the $\Delta \mathrm{T}_{\min }$ of $20^{\circ} \mathrm{C}$. This implies that there is a potential for generating more steam from the
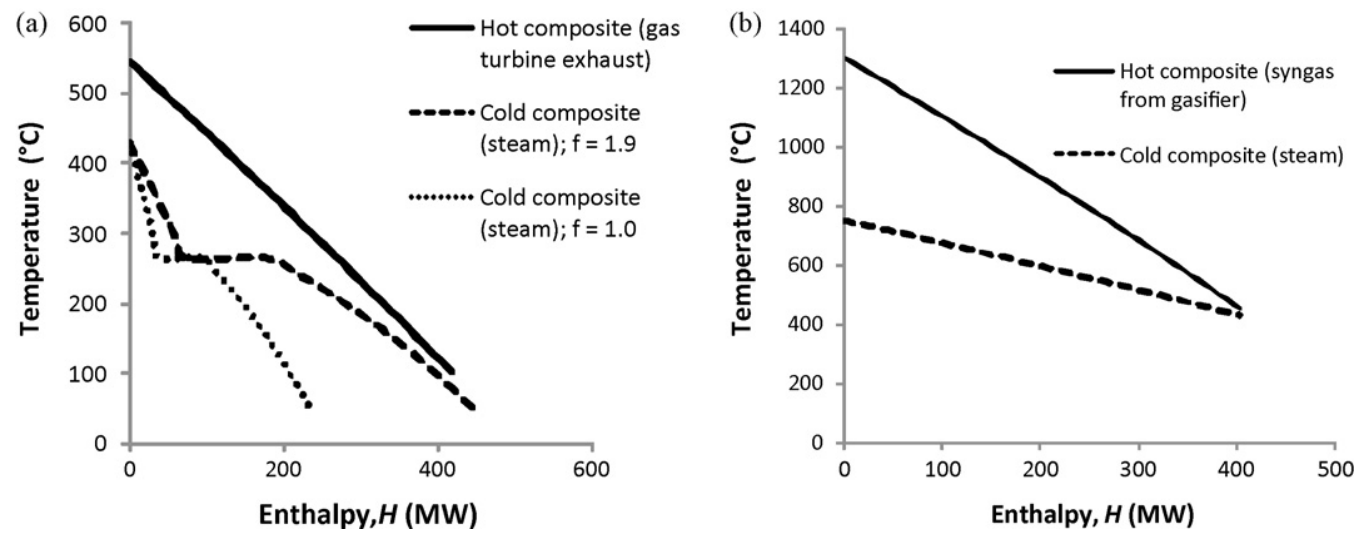

Fig. 4 - (a) Composite curves for Case A.1 showing the heating of BFW to generate saturated steam at $264^{\circ} \mathrm{C}$, followed by superheating the steam to $430^{\circ} \mathrm{C}$ using gas turbine exhaust in the HRSG. (b) Composite curves for Case A.1 showing the superheated steam generated at $750^{\circ} \mathrm{C}$ using syngas in the SYNGCOOL. 

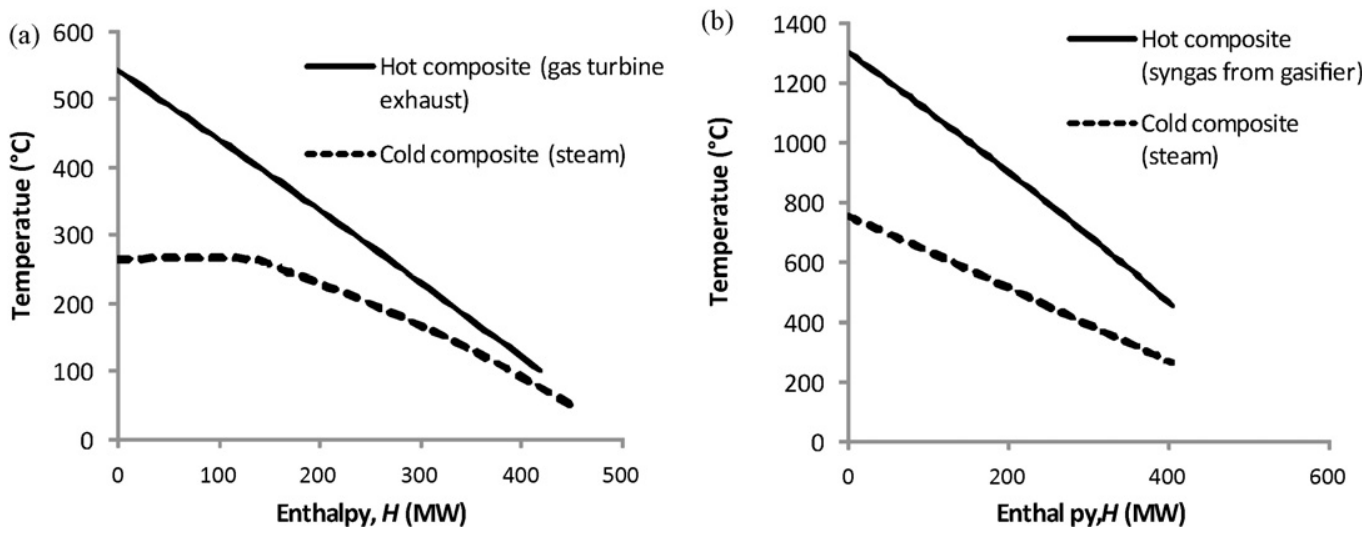

Fig. 5 - (a) Composite curves for Case A.2 showing the heating of BFW to generate saturated steam at $264^{\circ} \mathrm{C}$ using gas turbine exhaust in the HRSG. (b) Composite curves for Case A.2 showing the superheated steam generated at $750^{\circ} \mathrm{C}$ using syngas in the SYNGCOOL.

HRSG than that required by the site. Therefore, the amount of steam generation could be increased, or the cold composite curve could be shifted horizontally, closer to the hot composite curve, until the given $\Delta \mathrm{T}_{\min }$ of $20^{\circ} \mathrm{C}$ between the hot and cold composite curves is obtained. Thus, a factor $f$ was used to identify the excess steam that can be generated (see Fig. 3) as in Eq. (2a).

The maximum steam generation from HRSG for Case A.1

$$
=f \times\left[\left(m_{\mathrm{LTWGS}}^{u}+m_{\mathrm{HTWGS}}^{u}+m_{\text {gasifier }}^{u}\right)+\left(m_{\mathrm{HTWGS}}^{u}+m_{\text {gasifier }}^{u}\right)\right]
$$

The procedure for maximising the heat recovery while meeting $\Delta T_{\min }$ of $20^{\circ} \mathrm{C}$ is illustrated in Fig. 4(a). A value of $f$ of 1.9 was determined to be the maximum by assuming $\Delta T_{\min }$ of $20^{\circ} \mathrm{C}$. The steam generated from HRSG is transferred to SYNGCOOL for superheating to $750^{\circ} \mathrm{C}$. The mass flow rate of steam in the SYNGCOOL has been taken as in Eq. $(2 b)$, where $F$ is the factor to be manipulated in order to meet the $\Delta T_{\text {min }}$ of $20^{\circ} \mathrm{C}$ between the hot (syngas) and cold (steam from HRSG) composite curves.

The maximum steam generation from SYNGCOOL for Case A.1

$=F \times\left[(f-1) \times m_{\mathrm{HTWGS}}^{u}+f \times m_{\text {gasifier }}^{u}\right]$

An additional factor, $F$ of 3.4 is obtained for Case A.1. Fig. 4(b) shows the composite curves for superheating the steam to $750^{\circ} \mathrm{C}$ in SYNGCOOL for Case A.1.

For Case A.2 there are two segments in the cold composite curve, one for heating the BFW to $264^{\circ} \mathrm{C}$ and another to saturate to steam at the same temperature, while extracting heat from the gas turbine exhaust in the HRSG. Eq. (2c) shows the maximum steam generation from HRSG for Case A.2, where same equation was applied for both segments.

The maximum steam generation from HRSG (both segments) for Case A.2

$=F \times\left(m_{\text {LTWGS }}^{u}+m_{\text {HTWGS }}^{u}+m_{\text {gasifier }}^{u}\right)$

The factor, $F$ has been found to be 2.3. Fig. 5(a) illustrates the composite curves for saturating the steam to $264^{\circ} \mathrm{C}$. The saturated steam is then sent to the SYNGCOOL to superheat to $750^{\circ} \mathrm{C}$. There are also two segments for the cold composite curve, one for superheating the steam from $264^{\circ} \mathrm{C}$ to $430^{\circ} \mathrm{C}$ (first segment) and another for superheating the steam from $430^{\circ} \mathrm{C}$ to $750^{\circ} \mathrm{C}$ (second segment). The maximum steam gen- eration from SYNGCOOL for Case A.2 are the sum of mass flow rates estimated from Eqs. (2d) and (2e).

The mass flow rate of steam of the first segment from SYNGCOOL for Case A.2

$=F \times\left[(f-1) \times m_{\text {LTWGS }}^{u}+f \times\left(m_{\text {HTWGS }}^{u}+m_{\text {gasifier }}^{u}\right)\right]$

The mass flow rate of steam of the second segment from SYNGCOOL for Case A.2

$=F \times\left[(f-1) \times\left(m_{\text {LTWGS }}^{u}+m_{\text {HTWGS }}^{u}\right)+f \times m_{\text {gasifier }}^{u}\right]$

The value of $f$ of 1.9 follows the results from Case A.1. The additional factor, $F$ has been found to be 2.2. Fig. 5(b) shows the composite curves for superheating the steam to $750^{\circ} \mathrm{C}$ in SYNGCOOL for Case A.2.

There is an anomaly existing in the composite curves shown in Fig. 5(b), i.e. the cold composite curve does not approach closely to the hot composite curve and the pinch point temperature is larger than the $\Delta T_{\text {min }}$. In this case, both the inlet and outlet temperatures of steam are fixed and cannot be changed. The inlet temperature of steam is fixed since the steam is transferred from HRSG, while the target temperature is set at the maximum superheating temperature of $750^{\circ} \mathrm{C}$. Mass flow rate of steam is the only parameter that can be manipulated. However, increasing the factor (hence increasing the mass flow rate of steam) only extends the cold composite curve beyond the enthalpy change or heat recovery from the hot composite curve. Hence, meeting the minimum temperature driving force or maximum heat recovery in SYNGCOOL cannot be achieved for Case A.2.

\subsubsection{Mass balance of steam and water on the site}

The steam balances around the CHP network were performed for estimating the power generation and preheating of streams and fulfilling the site steam requirement, as shown in Figs. 6-8 for the three cases. The steps were as follows:

1. An initial $T_{\text {max,preheat, }}$ maximum preheat temperature of BFW, was estimated based on heat recovery from HTWGS and LTWGS, $\dot{Q}_{i}$ (see Table 4) using Eq. (3). $m_{i}^{g}$ is the mass flow rate of $B F W$ preheated using process heat. $C_{p, L}$ and $T_{\text {supply }}$ are the specific heat capacity and the supply temperature of BFW, respectively. $\mathrm{T}_{\text {supply }}$ of BFW was taken to be at $25^{\circ} \mathrm{C}$.

$\dot{\mathrm{Q}}_{i}=m_{i}^{g} \mathrm{C}_{p, L}\left(\mathrm{~T}_{\text {max }}\right.$ preheat $\left.-\mathrm{T}_{\text {supply }}\right)$ 


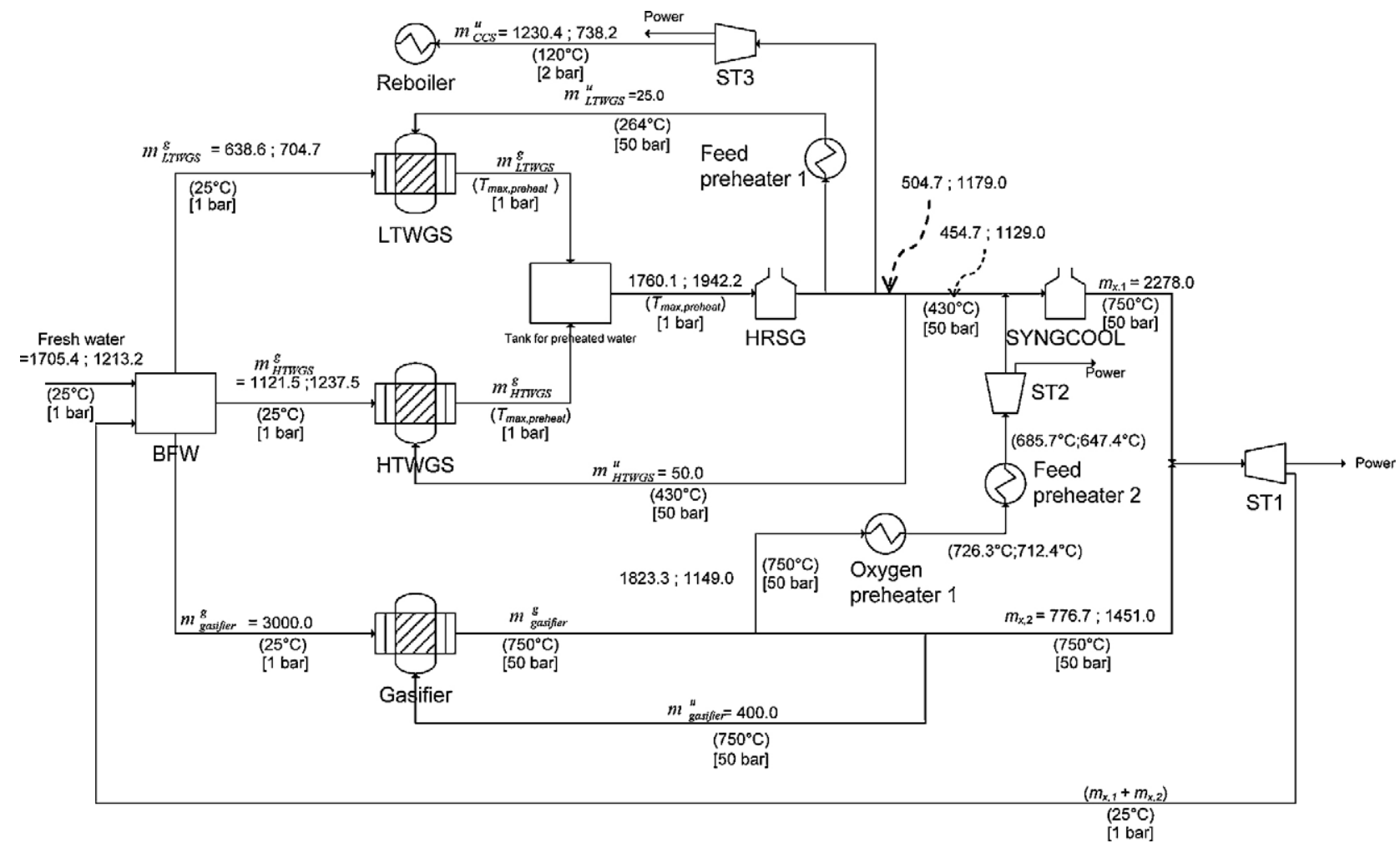

Fig. 6 - The CHP network for Case A.1 and Case B with 100\% and 60\% decarbonisation respectively and steam superheating at $430^{\circ} \mathrm{C}$ in $\mathrm{HRSG}$.

2. The flow rate of steam generated from HRSG was estimated by using pinch analysis discussed in Section 2.3.3.

3. The sum of $m_{\text {LTWGS }}^{g}$ and $m_{\text {HTWGS }}^{9}$ obtained from step 1 was compared with the flow rate of the steam obtained in step 2 (see Figs. 6-8).

4. The final maximum preheat temperature of BFW was obtained when the discrepancy between the mass flow rates of $\mathrm{BFW}$ and steam was less than $1 \%$, by repeating steps $1-3$.

Eq. (4) was used to calculate the mass flow rate of steam generating, $m_{\text {gassifier }}^{g}$, utilising the exothermic heat of the gasifier $\left(\dot{Q}_{i}\right.$ provided in Table 4). $T_{\text {sat }}$ and $T_{\text {final }}$ are the saturation

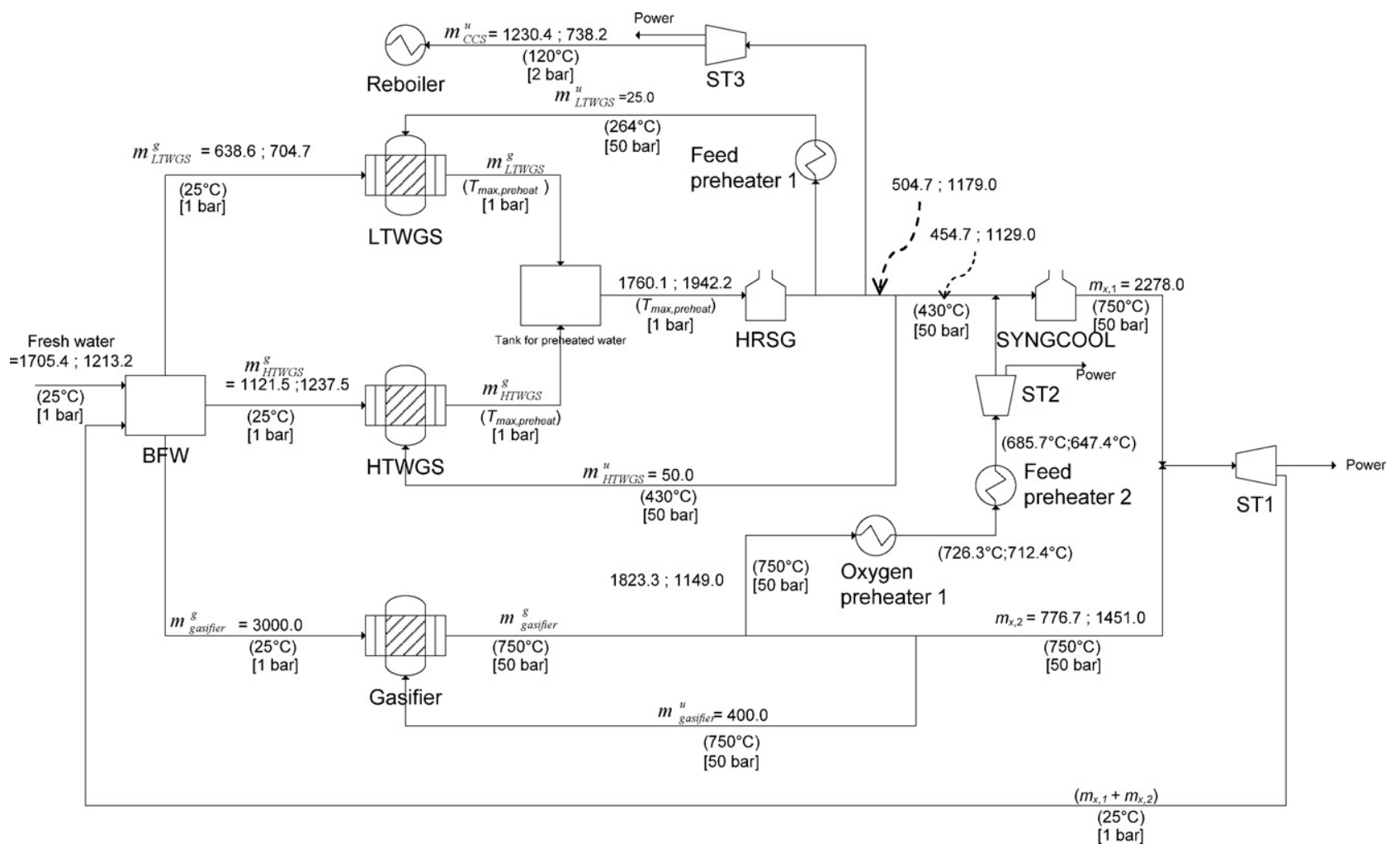

Fig. 7 - The CHP network for Case A.2 with $100 \%$ decarbonisation and steam superheating at $264^{\circ} \mathrm{C}$ in $\mathrm{HRSG}$. 


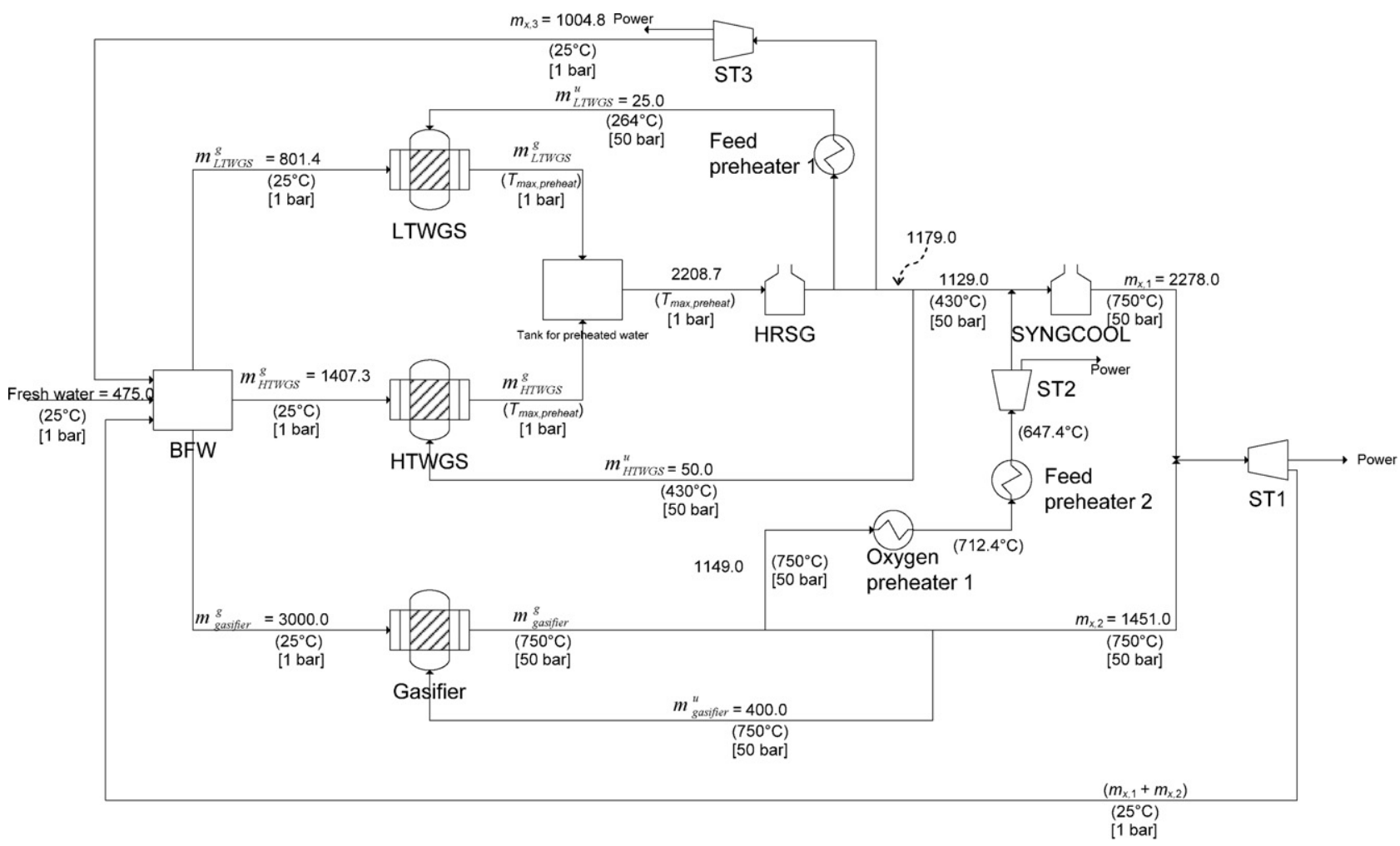

Fig. 8 - The CHP network for Case C with $0 \%$ decarbonisation and steam superheating at $430^{\circ} \mathrm{C}$ in HRSG.

and superheat temperatures of the steam respectively. $\Delta h^{\text {vap }}$ is the heat of vaporisation of BFW at $T_{s a t} . C_{p, G}$ is the specific heat capacity of the superheated steam.

$\dot{\mathrm{Q}}_{i}=m_{\text {gasifier }}^{g}\left[C_{p, L}\left(\mathrm{~T}_{\text {sat }}-\mathrm{T}_{\text {initial }}\right)+\Delta h^{\text {vap }}+\int_{\mathrm{T}_{\text {sat }}}^{\mathrm{T}_{\text {final }}} C_{p, G} \mathrm{dT}\right]$

The steam supplied to the reboiler of the CCS unit, $m_{C C S}^{u}$, which varies with the degree of decarbonisation, was determined using Eq. (5). The reboiler in the CCS unit operates at a temperature of $120^{\circ} \mathrm{C}$ (Tobiesen and Svendsen, 2005) and requires low pressure saturated steam at approximately 2 bar $\left(m_{C C S}^{u}\right)$. The thermal heat required in the reboiler was assumed to be $3.89 \mathrm{GJ} / \mathrm{t}$ of $\mathrm{CO}_{2}$ (Abu-Zahra et al., 2007). For $100 \%$ decarbonisation, $696.7 \mathrm{th}^{-1}$ of $\mathrm{CO}_{2}$ has to be removed, as obtained from simulation.

$\dot{\mathrm{Q}}_{\mathrm{i}}=m_{\mathrm{i}}^{u} \Delta h^{\mathrm{vap}}$

The excess steam $\left(m_{x, 1}\right.$ and $\left.m_{x, 2}\right)$ is utilised to generate power by expanding through the steam turbines. The pressure of the excess steam at 50 bar is reduced down to 1 bar and $\mathrm{BFW}$ at $25^{\circ} \mathrm{C}$ is produced, which is then recycled to the boiler feed water (BFW) tank. Eq. (6) was applied to balance the mass flow rate of BFW across a site.
Mass flow rate of fresh BFW required

$=m_{\text {LTWGS }}^{g}+m_{\text {HTWGS }}^{g}+m_{\text {gasifier }}^{g}-m_{x, 1}-m_{x, 2}-m_{x, 3}$

\subsubsection{Preheating feed and $\mathrm{O}_{2}$ streams}

Preheating of feed streams can be optional however can enhance the overall performance of the gasification reactions, if site-wide surplus heat is available. The coal slurry can be preheated up to a maximum temperature of $300^{\circ} \mathrm{C}$, so that sticking of the coal particles can be avoided while achieving better preheating effect (Holt, 2001; Higman and Burgt, 2008). $\mathrm{O}_{2}$ was preheated up to $600^{\circ} \mathrm{C}$ (Kakaras et al., 2006). Preheating of these streams can be done by utilising steam that is not used otherwise.

Additionally, the sequential arrangement of the preheaters needed to be addressed. Applying the generic thermodynamic matching rule and hottest/highest heuristic as illustrated in Section 2.3.2, the stream with a higher temperature driving force is utilised to preheat the feed or $\mathrm{O}_{2}$ to the highest temperature and vice versa. The preheat temperatures of the feed and $\mathrm{O}_{2}$ were determined iteratively using a heat balance as illustrated in Section 2.3.4.

Once all the steam balance results were collected the process flow sheet was re-simulated with the updated values of the process variables such as the temperature and pressure

Table 6 - Case studies with different conditions and CHP networks in terms of the degree of decarbonisation and the temperature of steam generated from HRSG.

\begin{tabular}{lccc} 
Case study & Degree of decarbonisation (\%) & Temperature of steam generated from HRSG $\left({ }^{\circ} \mathrm{C}\right)$ & CHP network \\
\hline Case A.1 & 100 & 430 & Fig. 6 \\
Case A.2 & 100 & 264 & Fig. 7 \\
Case B & 60 & 430 & Fig. 6 \\
Case C & 0 & 430 & Fig. 8 \\
\hline
\end{tabular}


of steam and preheat temperatures of feed and $\mathrm{O}_{2}$, etc. This was to ensure that the changes in the heat duties of the corresponding units were within permissible limits of less than $1 \%$ discrepancy. If the discrepancy was more than $1 \%$, the steam balance was revised.

\subsubsection{Estimation of power generation}

Power generation from the steam turbines forms the heart of the CHP concept. The power generated from the steam turbines is crucial since it determines both the economic viability of a CHP network in terms of the operating costs and also the impact of different degrees of decarbonisation. An optimum network is the one that generates the highest power from the steam turbine while providing a promising return on investment. ASPEN Plus simulation was used to estimate the power generation from the gas turbine, which varies with the degree of decarbonisation. The stream data from the CHP network such as mass flow rate, temperature and pressure of steam were required to simulate the power generation from the steam turbines. STAR, a software package developed in the Centre for Process Integration at The University of Manchester, was used to predict the power generation from the steam turbines. It provides the analytical and optimisation tools for the design of the site utility and cogeneration systems (The University of Manchester, 2008).

\subsection{Economic analysis and cost of electricity}

The economic analysis plays an important role in providing quantitative evaluation of the economic worthiness of a particular project, from which can opt for the most economical strategy (Sadhukhan et al., 2008). The analysis begins with the capital and operating costs evaluation of the site, followed by the discounted cash flow analysis. Consequently, the cost of electricity production can be proposed.

\subsubsection{Capital cost analysis}

The correlations/references for various capital cost items are indicated later in the case study results. For approximating the capital costs of gas turbines (NETL, 2002), steam turbines (NETL, 2002) and boilers (Sinnott, 2006), a reasonable number of sub-units are assumed. This is because the correlations provided can only approximate the costs up to a certain limit of power generation. The costs predicted from this method may be regarded as an indicative value. In an actual case, the bulk purchase cost should be taken into account where discounted costs are offered by the manufacturer. Also, the costs and choices of industrial gas turbines may also have an impact on the total capital investment. For the purpose of preliminary cost estimation for examining the viability of a CHP network, use of the correlations to obtain the costs is adequate. The purchased costs of equipment were obtained in different years and levelised by using Eq. (7) and cost index (Peters et al., 2003). The cost index is taken from Chemical Engineering Plant Cost Index (CEPCI) and is published monthly in Chemical Engineering (Economic Indicators, 2009). The index value as per December 2008 is 548.4 .

Present cost $=$ Original cost

$$
\times \frac{\text { Index at present }}{\text { Index when original cost was obtained }}
$$

\subsubsection{Operating cost analysis}

The operating costs can be divided into two main categories: fixed and variable operating costs. The total number of personnel has been estimated to be 128 , and it has also been assumed that the average cost to employ a labourer is $£ 37500$ per year (IEA, 2003). The total operating hour has been assumed to be $8000 \mathrm{~h} /$ year. Other additional costs such as the costs for research and development, sales expenses and general overheads need to be added to the total operating cost (Sinnott, 2006).

The BFW consumption in the CCS unit has been estimated to be $96.86 \mathrm{~m}^{3} / \mathrm{t} \mathrm{CO}_{2}$ removed (Abu-Zahra et al., 2007). The raw material used on the site is MDEA solvent, besides the coal. IEA (2003) presents an estimation of the mass flow rate of the solvent required as $8.36 \times 10^{-3} \mathrm{th}^{-1}$ for $100 \% \mathrm{CO}_{2}$ removal. Since the solvent can be regenerated in the stripper column, unless a detailed simulation on the absorber and stripper columns in the CCS unit is performed, it is difficult to optimise the mass flow rate of the solvent to be used (Lou et al., 2008). In this case a proportional value based on MDEA solvent requirement for $100 \%$ decarbonisation has been used for predicting the cost of solvent used in CCS unit.

Table 7 - Power generation/consumption and net power/electricity generation for Cases A.1, A.2, B, C and without heat

\begin{tabular}{|c|c|c|c|c|c|}
\hline Case study & Case A.1 & Case A.2 & Case B & Case C & $\begin{array}{c}\text { Case of } 100 \% \\
\text { decarbonisation and } \\
\text { without heat integration }\end{array}$ \\
\hline Degree of decarbonisation (\%) & 100 & 100 & 60 & 0 & 100 \\
\hline Total power generation (MW) & 1930 & 1764 & 2056 & 2146 & 810 \\
\hline 1. Gas turbine & 810 & 810 & 866 & 890 & 810 \\
\hline 2. ST1 & 840 & 657 & 1025 & 1025 & - \\
\hline 3. ST2 & 83 & 139 & 47 & 47 & - \\
\hline 4. ST3 & 197 & 130 & 118 & 184 & - \\
\hline 5. ST4 & - & 28 & - & - & - \\
\hline Total power consumption (MW) & 413 & 413 & 386 & 346 & 413 \\
\hline Net power generation (MW) & 1517 & 1351 & 1670 & 1800 & 397 \\
\hline Net electricity generation per year $\left(\times 10^{7} \mathrm{MWh}\right)$ & 1.21 & 1.08 & 1.34 & 1.44 & 0.32 \\
\hline Net energy efficiency based on LHV of feedstock (\%) & 57.8 & 51.5 & 63.6 & 68.6 & 15.1 \\
\hline
\end{tabular}
integration. 
2.4.3. Discounted cash flow analysis, cost of electricity

(COE) and evaluation of $\mathrm{CO}_{2}$ emission trading value

Discounted cash flow (DCF) converts the projected future value of the cash flow into the present value, by applying a discount rate. This analysis aims to evaluate and determine the potential of an investment (Sadhukhan et al., 2008).

To begin with, the future value of money needs to be converted into the present value. This is because DCF uses a cumulative cash flow method based on present value evaluation. Eq. (8) shows the calculation of the present value from future value, by applying a discount rate, $r$ (Sinnott, 2006). The present value will become the discounted cash flow for each year. The present value is lower than the future value since the money in the present is more valuable than in the future. This is the reason of using the discount rate to predict the "worthiness" of the future money in the present context.

Present value $=\frac{\text { Future value }}{(1+r)^{n}}$

where $n$ is the number of years.

The cumulative discounted cash flow is expressed as the net present value (NPV) in DCF analysis. NPV is calculated as shown in Eq. (9) (Sinnott, 2006). $C_{f}$ is the cash flow in a particular year. $T_{P L}$ is the plant life.

$\mathrm{NPV}=\sum_{n=0}^{n=T_{\mathrm{PL}}} \frac{C_{f}}{(1+r)^{n}}$

The cost of electricity (COE) is a meaningful value for comparing the economic potential of the CHP network in different cases. This section aims to deduce $\mathrm{COE}$ and also an estimated $\mathrm{CO}_{2}$ emission trading value.

After evaluating the capital costs (CAPEX), operating costs (OPEX) and DCF, the cost of electricity (COE) is calculated. COE is calculated using Eq. (10) (Sadhukhan et al., 2003). unit reboiler and gasifier provided in Table 4. Therefore, this superheated steam generating from HRSG and gasifier could be used for preheating or power generation through steam turbines. $25 \mathrm{th}^{-1}$ of saturated steam at $264^{\circ} \mathrm{C}$ and $50 \mathrm{bar}$ is required for LTWGS (Table 4) and hence can be supplied from the superheated steam generating at $430^{\circ} \mathrm{C}$ from HRSG, after extracting heat from it through preheaters. Further, this superheated steam generating from HRSG can supply $1230.4 \mathrm{th}^{-1}$ and $738.2 \mathrm{th}^{-1}$ of steam required by CCS unit reboiler in Cases A.1 and B, respectively, after reducing from 50 bar to 2 bar through the steam turbine, ST3. For Case $\mathrm{C}$, without any $\mathrm{CO}_{2}$ capture, this whole amount of steam $\left(1004.8 \mathrm{th}^{-1}\right)$ can be converted to BFW after power generation through steam turbines, ST3. The steam generated from HRSG is then utilised to fulfil the steam requirement of $50 \mathrm{th}^{-1}$ of HTWGS. The balance of superheated steam generated at $430^{\circ} \mathrm{C}$ from HRSG can be further superheated in SYNGCCOL. It can be noted that this steam from HRSG does not recover the heat available in SYNGCOOL completely (Table 4). Further, $2278 \mathrm{th}^{-1}$ of steam needs to be superheated in SYNGCOOL in order to maximise the heat recovery from syngas in SYNGCOOL, as illustrated in Fig. 6. This steam can be supplied from the superheated steam generating at $750^{\circ} \mathrm{C}$ and 50 bar utilising the exothermic heat of the gasifier, after extracting heat from it through preheaters and steam turbines. The superheated steam of $3000 \mathrm{th}^{-1}$ at $750^{\circ} \mathrm{C}$ and 50 bar generated by utilising exothermic heat of the gasifier is also used to supply steam for the gasification reaction (Table 4). The balance of the superheated steam from gasifier can be sent to steam turbines, ST1, to produce power before being returned as BFW. $\mathrm{T}_{\text {max,preheat }}$ was determined to be $89^{\circ} \mathrm{C}, 128^{\circ} \mathrm{C}, 83^{\circ} \mathrm{C}$ and $89^{\circ} \mathrm{C}$ for Cases A.1, A.2, B and C, respectively, by means of the iterative algorithm (see Section 2.3.4 steps 1-4). Next, the arrangement of the preheaters in these cases was decided using thermodynamic and heat integration heuristics discussed in Section 2.3.2. The superheated steam generated from HRSG is first used to preheat the feedstock

$\mathrm{COE}=\frac{\text { Annualised capital cost }+\mathrm{OPEX}+\mathrm{CO}_{2} \text { emission trading value (where relevant) }}{\text { (wetpower }}$ Net power generation per year

\section{Case studies and discussion}

The objective of performing the case studies was to decide which CHP network (Case A.1 or Case A.2 in Section 2.3.2) is the most attractive in terms of power generation. The better CHP network was then investigated for different degrees of decarbonisation in Cases B and C presented in Table 6. Finally, these cases were studied for economic evaluation in detail, presented in Section 3.3 .

\subsection{Maximum heat recovery CHP networks}

Figs. 6-8 present the proposed maximum heat recovery (energy efficiency) CHP networks for Cases A.1, B, A.2 and C respectively. The methodology for performing the steam balance is illustrated in Section 2.3.4. The mass flow rates of steam derived from the steam balance are summarised in the respective figures. The rest of the steam flow rates in Figs. 6-8 are predicted based upon mass balances or heat integration exercises on the total site in order to maximise power generation from the steam turbines.

In Cases A.1, B and C, the superheated steam generating from $\mathrm{HRSG}$ and gasifier at $430^{\circ} \mathrm{C}$ and $750^{\circ} \mathrm{C}$ respectively, is in excess of the steam requirements by HTWGS, LTWGS, CCS to gasifier in Feed preheater 1, before being sent to LTWGS, as this has a lower temperature driving force than the steam generating from gasifier. The superheated steam generated from gasifier has very high heat content such that it is able to preheat the feed slurry and oxygen streams. After the Oxygen preheater 1 , the steam is sent through steam turbines (ST2) before being sent to the SYNGCOOL for superheating. Feed preheater 1, Feed preheater 2 and Oxygen preheater 1 are used in those streams instead of steam turbines since the power generated through steam turbines is lower and insignificant (i.e. more than 40 times lower due to power generation efficiency through steam turbines) compared to the power generated from the excess steam. Hence, our target is to maximise heat integration among processes before utilising excess heat/steam for power generation. If Feed preheater 1 was replaced by a steam turbine, only $1.8 \mathrm{MW}$ of power can be generated. Furthermore, only $28.8 \mathrm{MW}$ of power can be generated if both Feed preheater 2 and Oxygen preheater 1 were replaced by steam turbines.

Similar design procedures are repeated for Case A.2. The CHP network in Case A.1 is preferable to that of Case A. 2 from a thermodynamic perspective, since it gives greater power generation. This will be shown in Section 3.2. Therefore, the CHP network for Case B is taken to be identical to that in Case A.1 


\section{Table 8 - Gapital cost evaluation for each case study.}

\begin{tabular}{|c|c|c|c|c|c|c|c|c|c|}
\hline \multirow[t]{2}{*}{ Item/specification } & \multirow[t]{2}{*}{ Cost estimation } & \multicolumn{2}{|c|}{ Case A.1 } & \multicolumn{2}{|c|}{ Case A.2 } & \multicolumn{2}{|c|}{ Case B } & \multicolumn{2}{|c|}{ Case C } \\
\hline & & Parameter $^{\mathrm{a}}$ & Cost (£million) & Parameter $^{\mathrm{a}}$ & Cost (£million) & Parameter $^{\mathrm{a}}$ & Cost (£million) & Parameter $^{\mathrm{a}}$ & Cost (£million) \\
\hline \multicolumn{10}{|l|}{ Direct capital costs } \\
\hline \multicolumn{10}{|l|}{ ISBL } \\
\hline 1. Gasifier & $£ 12.5 \mathrm{~kg}^{-1}$ day $^{-}$coal $^{\mathrm{b}}$ & $6.81 \times 10^{6}$ & 118.0 & $6.81 \times 10^{6}$ & 118.0 & $6.81 \times 10^{6}$ & 118.0 & $6.81 \times 10^{6}$ & 118.0 \\
\hline 2. $\mathrm{H}_{2} \mathrm{~S}$ removal unit & $£ 200 \mathrm{~kg}^{-1}$ day $^{-}$sulphur ${ }^{\mathrm{b}}$ & $6.96 \times 10^{4}$ & 19.3 & $6.96 \times 10^{4}$ & 19.3 & $6.96 \times 10^{4}$ & 19.3 & $6.96 \times 10^{4}$ & 19.3 \\
\hline 3. Water-gas shift reactor & $£ 10 \mathrm{~kg}^{-1}$ day $^{-1} \mathrm{CO}_{2} \mathrm{~b}, \mathrm{c}$ & $1.67 \times 10^{7}$ & 231.8 & $1.67 \times 10^{7}$ & 231.8 & $1.67 \times 10^{7}$ & 231.8 & $1.67 \times 10^{7}$ & 231.8 \\
\hline 4. CCS unit & $£ 10.5 \mathrm{MWh}^{-1}$ electricity ${ }^{\mathrm{d}}$ & $1.21 \times 10^{7}$ & 149.2 & $1.08 \times 10^{7}$ & 132.9 & $1.34 \times 10^{7}$ & 164.3 & - & - \\
\hline 5. Gas turbine & Correlations $\mathrm{e}^{\mathrm{e}}$ & 4 & 97.0 & 4 & 97.0 & 4 & 104.0 & 4 & 110.9 \\
\hline 6. Steam turbine & Correlations $\mathrm{e}^{\mathrm{e}}$ & 55 & 74.5 & 52 & 45.7 & 85 & 86.6 & 105 & 90.1 \\
\hline 7. Boiler & Correlations $^{f}$ & 82 & 34.9 & 71 & 30.2 & 85 & 36.2 & 94 & 40.0 \\
\hline 8. ASU & $£ 14 \mathrm{~kg}^{-1}$ day $^{-1} \mathrm{O}_{2}{ }^{\mathrm{b}}$ & $4.80 \times 10^{6}$ & 93.2 & $4.80 \times 10^{6}$ & 93.2 & $4.80 \times 10^{6}$ & 93.2 & $4.80 \times 10^{6}$ & 93.2 \\
\hline \multicolumn{10}{|l|}{ OSBL } \\
\hline 9. General facilities & $30 \%$ of ISBL & & 245.4 & & 230.5 & & 256.0 & & 211.0 \\
\hline Total direct capital costs & & 1063.3 & & 998.6 & & 1109.4 & & 914.3 & \\
\hline \multicolumn{10}{|l|}{ Indirect capital costs $\mathrm{g}$} \\
\hline 10. Engineering permitting and start-up & $15 \%$ of ISBL & & 122.7 & & 115.2 & & 128.0 & & 105.5 \\
\hline 11. Contingency allowance & $10 \%$ of ISBL & & 81.8 & & 76.8 & & 85.3 & & 70.3 \\
\hline 12. Miscellaneous & $7 \%$ of ISBL & & 57.3 & & 53.8 & & 59.7 & & 49.2 \\
\hline Total indirect capital costs & & 261.8 & & 245.8 & & 273.0 & & 225.0 & \\
\hline Total CAPEX & & 1325.1 & & 1244.4 & & 1382.4 & & 1139.3 & \\
\hline $\begin{array}{l}\text { a Items } 1-3 \text { and } 8 \text { are estimated in terms of } n \\
\text { b The cost of the process unit is provided by } \\
\text { c The mass flow rate of } \mathrm{CO}_{2} \text { refers to } \mathrm{CO}_{2} \text { lea } \\
\text { d The cost of the CCS unit depends on the ne } \\
\text { per MWh electricity) which includes transp } \\
\text { e The correlations for estimating the costs of } \\
\text { f The correlations for estimating the costs of } \\
\text { g Simbeck and Chang (2002) provide the cost }\end{array}$ & $\begin{array}{l}\text { nass flow rate }\left(\mathrm{kg} \mathrm{day}^{-1}\right) \text {; ite } \\
\text { Simbeck and Chang }(2002) \text {, } \\
\text { ving the water-gas shift rea } \\
\text { et electricity generation (see } \\
\text { ortation and storage costs. } \\
\text { gas turbines and steam tur } \\
\text { boilers (HRSG and SYNGCC } \\
\text { estimation factor for OSBL }\end{array}$ & $\begin{array}{l}\text { An average cos } \\
\text { bines are provi } \\
\text { OL) are provide } \\
\text { and indirect ca }\end{array}$ & $\begin{array}{l}\text { nass flow rate of C } \\
\text { of } £ 1005 \text { ) gives per MWh } \\
\text { led by NETL (2002). } \\
\text { d by Sinnott (2006) } \\
\text { ital costs. }\end{array}$ & $\begin{array}{l}2 \text { captured. } \\
\text { range of the tot } \\
\text { lectricity has b } \\
\text { Refer to Sectior } \\
\text { Refer to Sectio }\end{array}$ & $\begin{array}{l}\text { l capital cost per } \\
\text { 2.4.1 for the app } \\
\text { 2.4.1 for the app }\end{array}$ & $\begin{array}{l}\text { nit electricity } \\
\text { Ifor year } 2005 \\
\text { ximation met] } \\
\text { ximation met }\end{array}$ & $\begin{array}{l}r \text { the CCS unit ir } \\
468.2 \text {. } \\
\text { ds. } \\
\text { ds. CEPCI for ye }\end{array}$ & $\begin{array}{l}\text { coal IGCC pou } \\
004 \text { is } 444.2 \text {. }\end{array}$ & plant (i.e. $£ 5-16$ \\
\hline
\end{tabular}




\begin{tabular}{|c|c|c|c|c|c|c|c|c|c|}
\hline \multirow[t]{2}{*}{ Specification } & \multirow[t]{2}{*}{ Cost estimation } & \multicolumn{2}{|c|}{ Case A.1 } & \multicolumn{2}{|c|}{ Case A.2 } & \multicolumn{2}{|c|}{ Case B } & \multicolumn{2}{|c|}{ Case C } \\
\hline & & $\begin{array}{l}\text { Mass flow rate } \\
\left(\mathrm{th}^{-1}\right)\end{array}$ & $\begin{array}{l}\text { Cost per year } \\
\text { (£million) }\end{array}$ & $\begin{array}{l}\text { Mass flow rate } \\
\left(\mathrm{th}^{-1}\right)\end{array}$ & $\begin{array}{l}\text { Cost per year } \\
\text { (£million) }\end{array}$ & $\begin{array}{l}\text { Mass flow rate } \\
\left(\mathrm{th}^{-1}\right)\end{array}$ & $\begin{array}{l}\text { Cost per year } \\
\text { (£million) }\end{array}$ & $\begin{array}{l}\text { Mass flow rate } \\
\left(\mathrm{th}^{-1}\right)\end{array}$ & $\begin{array}{l}\text { Cost per year } \\
\text { (£million) }\end{array}$ \\
\hline \multicolumn{10}{|c|}{ Fixed operating costs $(\mathrm{FOC})^{\mathrm{a}}$} \\
\hline 1. Maintenance & $10 \%$ of CAPEX & & 132.50 & & 124.44 & & 138.24 & & 113.93 \\
\hline 2. Operating labour & Refer to Section 2.3.2 & & 4.80 & & 4.80 & & 4.80 & & 4.80 \\
\hline 3. Laboratory cost & $20 \%$ of Specification 2 & & 0.96 & & 0.96 & & 0.96 & & 0.96 \\
\hline 4. Supervision & $20 \%$ of Specification 2 & & 0.96 & & 0.96 & & 0.96 & & 0.96 \\
\hline 5. Plant Overheads & $50 \%$ of Specification 2 & & 2.40 & & 2.40 & & 2.40 & & 2.40 \\
\hline 6. Capital Charges & $10 \%$ of CAPEX & & 132.50 & & 124.44 & & 138.24 & & 113.93 \\
\hline 7. Taxation & $2 \%$ of CAPEX & & 26.50 & & 24.89 & & 27.65 & & 22.79 \\
\hline 8. Insurance & $1 \%$ of CAPEX & & 13.25 & & 12.44 & & 13.82 & & 11.39 \\
\hline 9. Royalties and & 1\% of CAPEX & & 13.25 & & 12.44 & & 13.82 & & 11.39 \\
\hline \multicolumn{10}{|l|}{ license fees } \\
\hline Total FOC per year & & & 327.12 & & 307.77 & & 340.89 & & 282.55 \\
\hline \multicolumn{10}{|c|}{ Variable operating costs (VOC) ${ }^{\mathrm{b}}$} \\
\hline 10. Utility—BFW & $£ 0.015$ per ton & $6.92 \times 10^{4}$ & 8.31 & $6.92 \times 10^{4}$ & 8.31 & $4.17 \times 10^{4}$ & 5.00 & 475 & 0.06 \\
\hline (a) Fresh water & & $1.70 \times 10^{3}$ & & $1.70 \times 10^{3}$ & & $1.21 \times 10^{3}$ & & 475 & \\
\hline (b) CCS unit & & $6.75 \times 10^{4}$ & & $6.75 \times 10^{4}$ & & $4.05 \times 10^{4}$ & & 0 & \\
\hline 11. Solvent (MDEA) & $£ 3375$ per ton & $8.36 \times 10^{-3}$ & 0.23 & $8.36 \times 10^{-3}$ & 0.23 & $5.02 \times 10^{-3}$ & 0.14 & 0 & 0 \\
\hline 12. Feed (Coal) & $£ 30.5$ per ton & 283.7 & 69.22 & 283.7 & 69.22 & 283.7 & 69.22 & 283.7 & 69.22 \\
\hline $\begin{array}{l}\text { 13. Miscellaneous } \\
\text { materials }\end{array}$ & $10 \%$ of specification 1 & & 13.25 & & 12.44 & & 13.82 & & 11.39 \\
\hline Total VOC per year & & & 91.01 & & 90.20 & & 88.18 & & 80.67 \\
\hline \multicolumn{10}{|l|}{ Additional $\operatorname{coss}^{\mathrm{c}}$} \\
\hline $\begin{array}{l}\text { 14. Sales expense, } \\
\text { general overheads, } \\
\text { research and } \\
\text { development }\end{array}$ & $\begin{array}{l}20 \% \text { of total direct } \\
\text { production costs } \\
\text { (FOC + VOC) }\end{array}$ & & 83.63 & & 79.60 & & 85.82 & & 72.64 \\
\hline $\begin{array}{l}\text { 15. Coal } \\
\text { transportation }\end{array}$ & $£ 4.5$ per short ton & & 11.45 & & 11.45 & & 11.45 & & 11.45 \\
\hline $\begin{array}{l}\text { Total additional costs } \\
\text { per year }\end{array}$ & & 95.08 & & 91.05 & & 97.27 & & 84.09 & \\
\hline Total OPEX per year & & 513.21 & & 489.02 & & 526.34 & & 447.31 & \\
\hline
\end{tabular}


(see Fig. 6), but the degree of decarbonisation has been lowered to $60 \%$.

\subsection{Power generation as a criterion for an economically viable CHP network}

The power generation from the gas turbine was obtained from the ASPEN Plus simulation, while the power generation from the steam turbine was simulated in STAR, which requires data from the steam balance and the preheat temperatures (see Figs. 6-8). The objective was to compare the power generation between Cases A.1 and A.2, so that a preferred CHP network could be selected for studying the impact of different degrees of decarbonisation on the power generation in Cases B and C with $60 \%$ and without decarbonisation, respectively. The case without heat integration has also been performed by assuming $100 \%$ decarbonisation. The power generation from each case study is summarised in Table 7. As can be seen from Table 7 , the steam turbines constitute approximately $60 \%$ of power towards the total power generation. This has demonstrated the importance of the CHP concept where steam is used for power generation on the site. Case $C$ without decarbonisation was found to generate the highest amount of power as expected.

The net power generation includes power generation and consumption by the units, gasifier and pump used for transferring feed to gasifier, and the air compressor and $\mathrm{CO}_{2}$ compressor in the CCS unit, as illustrated in Fig. 2. The power consumed by the pump and air compressor was obtained from ASPEN Plus simulation, $0.5 \mathrm{MW}$ and $345 \mathrm{MW}$, respectively. These power consumptions are constant in all cases. The power consumed by the $\mathrm{CO}_{2}$ compressor obviously varies with the degree of $\mathrm{CO}_{2}$ capture. The power consumed for $\mathrm{CO}_{2}$ compression was determined to be $67 \mathrm{MW}$ and $40 \mathrm{MW}$
Table 10 - Economic assumptions for performing the discounted cash flow analysis (IEA, 2003).

\begin{tabular}{ll} 
Parameter & \multicolumn{1}{c}{ Assumption } \\
\hline Discount rate & $10 \%$ \\
Plant life & 25 years \\
Construction period & 3 years \\
Pay-back period & 25 years \\
CAPEX for year $-2,-1$ and 0 & $20 \%, 45 \%$ and $35 \%$, respectively \\
\hline
\end{tabular}

in Cases A.1-A.2 (also for case without heat integration) and $\mathrm{B}$, respectively. A total of 8000 operating hours per year was assumed.

This is obvious that the net power generation increases with the decreasing degree of decarbonisation (OrdoricaGarcia et al., 2006). Thus, there is a trade-off between the degree of decarbonisation and the economics. It has also been demonstrated in Table 7 that the net power generation efficiency based on LHV of the feedstock for the case of $100 \%$ decarbonisation and without heat integration is considerably lower (15.1\%) compared to the heat integrated cases derived, $57.8 \%, 51.5 \%, 63.6 \%$ and $68.6 \%$ for Cases A.1, A.2, B and C, respectively. The predicted cogeneration efficiencies are within the maximum range $65-75 \%$ that can be attained from gasification power plants (Simbeck, 2005).

\subsection{Economic evaluation}

Having established the role of the heat integration techniques in achieving a maximum heat recovery CHP network for a site, the final selection of the optimal CHP network was made by comparing the economics of the proposed networks.

\section{Table 11 - The discounted cash flow (DCF) evaluation for Case A.1.}

\begin{tabular}{|c|c|c|c|}
\hline Year & Cash flow, $C_{i}$ (£million) & Discounted cash flow (DCF) (£million) & NPV (£million) \\
\hline-2 & -265.0 & -265.0 & -265.0 \\
\hline-1 & -596.3 & -596.3 & -861.3 \\
\hline 0 & -463.8 & -463.8 & -1325.0 \\
\hline 1 & 146.0 & 132.7 & -1192.3 \\
\hline 2 & 146.0 & 120.6 & -1071.7 \\
\hline 3 & 146.0 & 109.7 & -962.0 \\
\hline 4 & 146.0 & 99.7 & -862.3 \\
\hline 5 & 146.0 & 90.6 & -771.7 \\
\hline 6 & 146.0 & 82.4 & -689.3 \\
\hline 7 & 146.0 & 74.9 & -614.4 \\
\hline 8 & 146.0 & 68.1 & -546.3 \\
\hline 9 & 146.0 & 61.9 & -484.4 \\
\hline 10 & 146.0 & 56.3 & -428.1 \\
\hline 11 & 146.0 & 51.2 & -376.9 \\
\hline 12 & 146.0 & 46.5 & -330.4 \\
\hline 13 & 146.0 & 42.3 & -288.1 \\
\hline 14 & 146.0 & 38.4 & -249.7 \\
\hline 15 & 146.0 & 34.9 & -214.7 \\
\hline 16 & 146.0 & 31.8 & -183.0 \\
\hline 17 & 146.0 & 28.9 & -154.1 \\
\hline 18 & 146.0 & 26.3 & -127.8 \\
\hline 19 & 146.0 & 23.9 & -104.0 \\
\hline 20 & 146.0 & 21.7 & -82.3 \\
\hline 21 & 146.0 & 19.7 & -62.5 \\
\hline 22 & 146.0 & 17.9 & -44.6 \\
\hline 23 & 146.0 & 16.3 & -28.3 \\
\hline 24 & 146.0 & 14.8 & -13.5 \\
\hline 25 & 146.0 & 13.5 & 0.0 \\
\hline
\end{tabular}


Table 12 - The annualised capital cost, OPEX, $\mathrm{CO}_{2}$ emission trading value and $\mathrm{COE}$ for each case.

\begin{tabular}{lcccc} 
Case & $\begin{array}{c}\text { Annualised capital } \\
\text { cost (fmillion/year) }\end{array}$ & $\begin{array}{c}\text { OPEX (£million/ } \\
\text { year) }\end{array}$ & $\begin{array}{c}\mathrm{CO}_{2} \text { emission trading } \\
\text { value (£million/year) }\end{array}$ & $\begin{array}{c}\text { COE (pence/ } \\
\mathrm{kWh})\end{array}$ \\
\hline A.1 & 146.0 & 513.2 & 0 & 5.43 \\
A.2 & 137.1 & 489.0 & 0 & 5.79 \\
B & 152.3 & 526.3 & 64.9 & 5.26 \\
C & 125.5 & 447.3 & 0 & 4.39 \\
$100 \%$ & 132.7 & 581.6 & & 22.47 \\
decarbonisation, & & & & \\
without heat & & & & \\
integration & & & & \\
\hline
\end{tabular}

\subsubsection{Capital cost and operating cost analysis}

The complete evaluation of capital and operating costs of each case study are presented in Tables 8 and 9, respectively. The methodologies for capital and operating costs analysis are outlined in Sections 2.4.1 and 2.4.2, respectively.

\subsubsection{Discounted cash flow (DCF) analysis for} determination of cost of electricity (COE)

The economic assumptions for evaluating the discounted cash flow analysis are given in Table 10. The operating years are taken as 25 years because most of the major vessels and equipment have a design life of 25 years (IEA, 2003). The DCF analysis is merely based on CAPEX. The annualised capital cost (the money for paying back the total CAPEX in each year) is determined by setting NPV equal to zero in year 25 .

The DCF analysis for Case A.1 is exemplified in Table 11 (refer to Eq. (9), Section 2.4.3). The annualised capital cost for Case A.1 has been predicted to be $£ 146$ million per year.

The annualised capital costs for each case are listed in Table 12. The same DCF analysis, discount rate and plant life as in Case A.1 were applied in other cases. The annualised capital costs solely reflect the amount of money needed to pay back each year for the investment in capital (Sadhukhan et al., 2003). In this study, the EU ETS price index of $11.65 € /$ tonne $\mathrm{CO}_{2}$ (equivalent to $10.6 £$ /tonne $\mathrm{CO}_{2}$, where $1 \mathrm{GBP}=1.1 €$ is assumed) (Argus, 2009) is used for estimating the $\mathrm{CO}_{2}$ emission trading value. The cost of $\mathrm{CO}_{2}$ emitted thus is taken into consideration when evaluating COE. Cases A.1 and A.2 are exempted from paying the cost for trading $\mathrm{CO}_{2}$ emission since $100 \%$ decarbonisation has been assumed in both of these cases. The mass flow rates of $\mathrm{CO}_{2}$ emitted from the site for Cases B and C are $278.7 \mathrm{th}^{-1}$ and $696.7 \mathrm{t} \mathrm{h}^{-1}$, respectively. COE is an indicator which shows a trend that a lower degree of decarbonisation has a lower COE and vice versa. COE depends on the net electricity generation, where net electricity generation is the highest at lower degree of decarbonisation. COE for each case was calculated using Eq. (10) and the results are summarised in Table 12.

In general, it is desired to have a lowest possible COE (Holt, 2004). COE for the case without heat integration (22.5 pence/kWh) is considerably higher than other cases with heat integration (Cases A.1, A.2, B and C with COE of 5.43, 5.79, 5.26 and 4.39 pence/ $\mathrm{kWh}$, respectively). It has been found that Case A.1 has a lower COE than Case A.2 (Table 12), and also the net electricity generation is higher in Case A.1 compared to Case A.2 (Table 7). This indicates that the CHP network in Case A.1 is superior to that in Case A.2 in terms of both economics and heat integration. Also, expectedly, CCS results in higher COE. The COE obtained from the IGCC cases was compared with the COE of other existing power plants, i.e. natural
Table 13 - Comparison of COE among various types of power plant with/without CCS.

\begin{tabular}{lcc} 
Power Plant & $\begin{array}{c}\text { COE without CCS } \\
\text { (pence/kWh) }\end{array}$ & $\begin{array}{c}\text { COE with CCS } \\
\text { (pence/kWh) }\end{array}$ \\
\hline $\mathrm{NGCC}^{\mathrm{a}}$ & 2.70 & 4.00 \\
$\mathrm{PC}^{\mathrm{a}}$ & 3.17 & 5.40 \\
$\mathrm{IGCC}^{\mathrm{b}}$ & 4.39 & 5.26
\end{tabular}

a COEs shown are representative values which based on average values from different studies (IPCC, 2005).

b COE taken for comparison is from Case B at $60 \%$ decarbonisation (see Table 12).

gas combined cycle (NGCC) and pulverised coal (PC) power plants with and without CCS (IPCC, 2005), as summarised in Table 13. CCS at this point refers to the $\mathrm{CO}_{2}$ capture with geological storage. This comparison signifies that IGCC is still less competitive in the current energy market due to the high COE for both with and without CCS facilities. Moreover, the price of $\mathrm{CO}_{2}$ emission allowances is very low, primarily due to the government policies which have set the emission cap too high, and consequently, it is not effective enough to encourage the industry to reduce their $\mathrm{CO}_{2}$ emission (Bossley and Kerr, 2007). This makes the realisation of CCS in IGCC technologies more challenging at this stage, unless a worldwide carbon tax regime is invoked and economic incentives for advancing the CCS technology are generated.

A sensitivity analysis (Fig. 9) has been performed to observe the impact on COE with the augmentation in CAPEX, i.e. increase by $30 \%, 60 \%$ and $90 \%$ of the present estimated CAPEX.

Fig. 10 features the sensitivity analysis of COE in terms of the $\mathrm{CO}_{2}$ emission trading value. This sensitivity analysis demonstrates that the COE varies by approximately $15 \%$ for Case B (60\% decarbonisation) and $44 \%$ for Case C $(0 \%$ decarbonisation), respectively, as the $\mathrm{CO}_{2}$ emission trading value

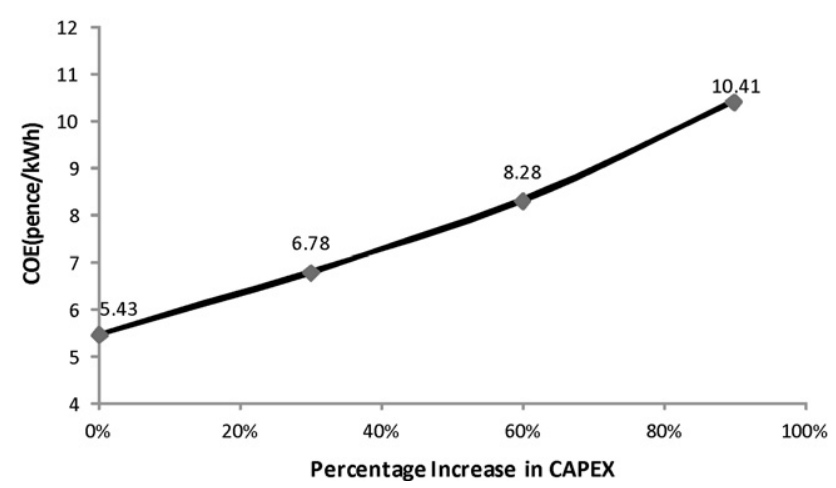

Fig. 9 - Sensitivity analysis of COE with CAPEX for Case A.1 (100\% decarbonisation). 


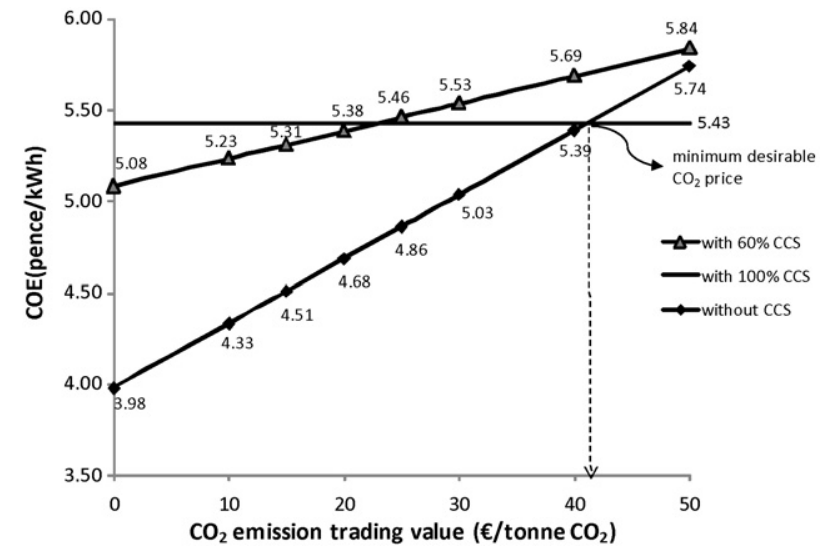

Fig. 10 - Sensitivity analysis of $\mathrm{COE}$ with $\mathrm{CO}_{2}$ emission trading value for different level of decarbonisation.

was varied from $0 € /$ tonne $\mathrm{CO}_{2}$ to $50 € /$ tonne $\mathrm{CO}_{2}$. Furthermore, the minimum desirable $\mathrm{CO}_{2}$ emission trading value was estimated from the interception point between the lines of the two extreme cases, i.e. $0 \%$ and $100 \%$ decarbonisation, which is approximately $42 € /$ tonne $\mathrm{CO}_{2}$. Obviously, above this value, IGCC without carbon capture becomes more expensive. A comparison between current $\mathrm{CO}_{2}$ emission trading value (Argus, 2009) and its minimum desirable value thus obtained also indicates that currently, there is no clear economic incentive for advancing CCS technology.

Fig. 11 shows the distribution of the major annual expenses on the site in each case. The major expenses are annualised capital costs and the costs of utility, raw material, feed and $\mathrm{CO}_{2}$ emission trading value.

It is evident that the capital cost is the highest contributor to the overall cost per year on the site, except for Case C. This is because the CCS unit for decarbonisation is capital intensive. This was partially offset by the design of the high efficiency CHP networks based on maximum heat recovery from the sites. Both the requirements of BFW and MDEA solvent vary depending on the degree of decarbonisation. In Fig. 11, the cost of coal is separated from the other raw material costs due to its substantially higher cost contribution, though independent of the degree of decarbonisation. Among all the cases, Case B with $60 \%$ decarbonisation is practically achievable. Case A.1 with $100 \%$ decarbonisation is technically impossible while Case $\mathrm{C}$ with $0 \%$ decarbonisation has a detrimental effect on the environment. Nevertheless, it is always recommended to study the whole range of decarbonisation for decision making.

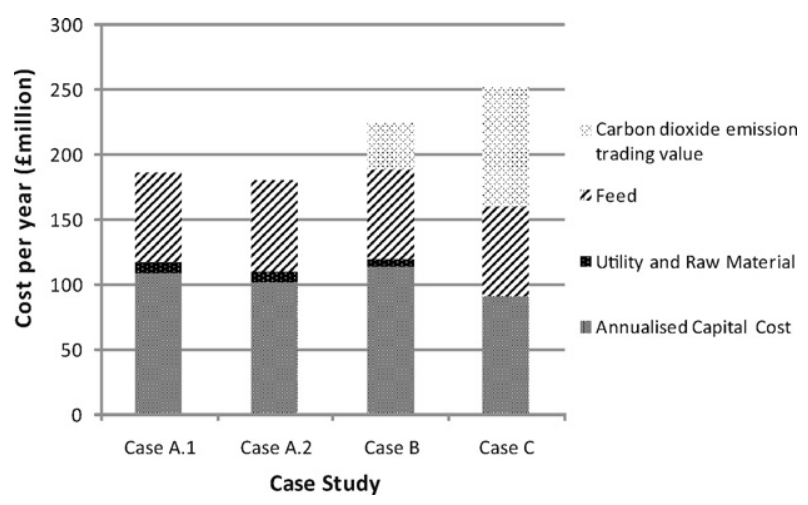

Fig. 11 - The distribution of major annual expenses (annualised capital cost, costs of utility and raw material, cost of feed and $\mathrm{CO}_{2}$ emission trading value) for each case.

\section{Conclusions and future works}

This paper elucidates heat integration methodologies on a coal IGCC site, where CHP networks have been proposed for sites with various degree of decarbonisation. The methodologies developed include comprehensive heat integration strategies based on pinch analysis and thermodynamic heuristics, following by economic evaluation. The importance of heat integration for the efficiency and economics of the site has been demonstrated, in terms of power generation and COE. The interrelationships between degree of decarbonisation, heat integration and economics have been studied. It has been found that a higher degree of decarbonisation results in lower power generation and higher COE.

The cost reduction of IGCC technology, enhancement of the efficiency of the site, and minimisation of the emission of greenhouse gases are the three main targets to improve the commercialisation and competitiveness of IGCC technology. There are several recommendations for further studies for achieving these targets:

(1) Various separation technologies for capturing $\mathrm{CO}_{2}$ (CCS unit) should be investigated since this contributes significantly towards the capital cost of IGCC site. It is envisaged that improvements of $\mathrm{CO}_{2}$ capture technologies could make IGCC more competitive compared to other types of power plant.

(2) Several issues and barriers related to CCS apart from high cost and energy consumption, need to be addressed. These involve lack of experience, uncertainty and ecological change that may be incurred in storing vast amount of $\mathrm{CO}_{2}$ in underground, especially from the power generation plants. Furthermore, a continuously evolving regulatory framework is imperative to support storage, decarbonisation and secure economic incentives over long term.

(3) Simultaneous optimisation of the process flow sheet and the heat recovery network to minimise the total cost of the site can be considered for overall improved performance of new IGCC plants with CCS, once the concept of CCS is proven.

(4) Renewable sources of energy such as biomass as an alternative feedstock in IGCC sites should be studied. The use of renewable sources of energy as the feedstock is more beneficial to the environment than using fossil fuel. However, renewable source of energy give lower thermal efficiency than the non-renewable sources. Furthermore, the non-renewable sources of energy such as coal are exhausting. Therefore, research is required for improving the energy efficiency of co-processing renewable resource. This could make IGCC more attractive in terms of fuel flexibility.

In conclusion, the recommendations stated above will possibly bring a promising future for IGCC technology where it can offer affordable energy for consumers, a cleaner environment for the community and the planet, and promising returns on investment for investors.

\section{References}

Abu-Zahra, M.R.M., Schneiders, L.H.J., Niederer, J.P.M., Feron, P.H.M. and Versteeg, G.F., 2007, $\mathrm{CO}_{2}$ capture from power plants. 
Part I. A parametric study of the technical performance based on Môn ethanolamine. Int. J. Green. Gas Cont. I, 37-46.

Argus, 2009, Argus Global Emissions. Vol. VIII, 4 April 2009. www.argusmedia.com (accessed 25 April 2009).

BC Sustainable Energy Association (BCSEA), 2007, Federal Pre-Budget Consultation Brief,

http://www.bcsea.org/solutions/government/policy/federalpre-budget-consultation-brief (accessed 6 January 2009).

Bohm, M., Herzog, H.J., Parsons, J.E. and Sekar, R.C., 2007, Capture-ready coal plants-options, technologies and economics. Int. J. of Green. Gas Cont. I, 113-120.

BP, Statistical Review Charting Tool: Coal Price from 1988. http://www. investis.com/bp_acc_ia/stat_review_05/htdocs/reports/report 22.html (accessed 10 December 2008).

Bossley, L. and Kerr, A., (2007). Climate Change and Emissions Trading: What Every Business Needs to Know (2nd edition). (Consilience Energy Advisory Group Ltd. (CEAG)).

Carbon Tax Center, 2008, What's a Carbon Tax. http://www.carbontax.org/ (accessed 24 March 2008).

Department for Environment, Food and Rural Affairs (DEFRA), 2007, Climate Change Agreements: The Climate Change Levy. http://www.defra.gov.uk/environment/climatechange/uk/ business/cca/levy.htm. (accessed 6 January 2009).

Department of Trade and Industry (DTI), 1998, Technology Status Report-Gasification of Solid and Liquid Fuels for Power Generation, DTI.

Driftmeier, W.H. (Alternate Energy Systems Inc.), 2004, Automatic Wobbe Index Control for Peak Shaving Plants, LP Symposium, Des Moines, 12-14 July.

Economic Indicators., 2009, Chem. Eng., 116(3): 64 (Retrieved from ABI/INFORM Global database, Document ID: 1670104061 (accessed 23 April 2009))

Environmental Investigation Agency (EIA), 2004, Coal Transportation: Rates and Trends. http://www.eia.doe.gov/ cneaf/coal/page/trans/ratesntrends.html (accessed 23 March 2008).

European Commission, 2005, EU Emissions Trading-An Open Scheme Promoting Global Innovation. European Commission, Directorate-General for the Environment, Brussels.

European Commission., 2007, Limiting global climate change to 2 degrees celsius: the way ahead for 2020 and beyond, In COM (2007) 2 final Brussels,

Guha, M.K., 2001, Advantage of integrated coal gasification combined cycle (IGCC) over other advanced generation technologies and its prospect in a competitive marketplace, In 18th Annual Pittsburgh Coal Conference Newcastle, Australia, 4 December,

Hara, S., Ashizawa, M. and Kidoguchi, K., 2003, R\&D of gasification technology for extra heavy oil-effects of steam injection on gasification characteristics and modeling of gasification reaction rate. Ann. Res. Rep. Cent. Res. Inst. Elec. Power Ind., 58-59.

Higman, C. and Burgt, M., (2008). Gasification (2nd edition). (Elsevier/Gulf Professional Publishing, Boston).

Holcomb, G.R., Alman, D.E., Bullard, S.B., Covino, B.S., Jr., Cramer, S.D. and Ziomek-Moroz, M., 2003, Ultra-supercritical steam corrosion, In 17th Annual Conference on Fossil Energy Materials Baltimore MD, 22-24 April,

Holt, N., 2001, Coal gasification research, development and demonstration-needs and opportunities, In Gasification Technologies Conference San Francisco CA, 10 October,

Holt, N., 2004, Gasification process selection-trade-offs and ironies, In The Gasification Technologies Conference Washington DC, 3-6 October,

International Energy Agency (IEA), 2003, Potential for improvement in gasification combined cycle power generation with $\mathrm{CO}_{2}$ capture, Report No. PH4/19, IEA.

International Energy Agency (IEA), 2006, IEA World Energy Outlook 2006, IEA.

Intergovernmental Panel on Climate Change (IPCC), 2005, IPCC Special Report on Carbon Dioxide Capture and Storage: Technical Summary (Cambridge University Press).
Kanniche, M. and Bouallou, C., 2007, $\mathrm{CO}_{2}$ capture study in advanced integrated gasification combined cycle. Appl. Therm. Eng., 27: 2693-2702.

Kakaras, E., Doukelis, A., Giannakopoulos, D. and Koumanakos, A., 2006, Novel concepts for near zero-emissions IGCC power plants. Therm. Sci., 10(3): 81-92.

Lee, C., Lee, S.J. and Yun, Y., 2007, Effect of air separation unit integration on integrated gasification combined cycle performance and $\mathrm{NO}_{x}$ emission characteristics. Korean J. Chem. Eng., 24(2): 368-373.

Linnhoff, B., (1998). Introduction to Pinch Technology. (Linnhoff March Energy Service).

Linnhoff, B., (2000). The Methodology and Benefits of Total Site Pinch Analysis. (Linnhoff March Energy Services).

Liu, Y.A., 1987, Process synthesis: some simple and practical development, in Recent Developments in Chemical Process and Plant Design, Liu, Y.A., McGee, H.A., \& Epperly, W.R. (eds) (John Wiley, New York), pp. 147-260.

Lou, Y., Smith, R. and Sadhukhan, J., 2008, Decarbonisation in energy production, In The AIChE Spring National Meeting New Orleans, 6-10 April,

Nag, P., LaGrow, M., Wu, J., Abou-Jaoude, K. and Engel, J., 2007, LNG fuel flexibility in Siemens' land-based gas turbine operations, In Electric Power Conference Chicago, 1-3 May,

National Mining Association (NMA), 2005, Clean Coal Technology: Current Progress, Future Promise, NMA.

National Energy Technology Laboratory (NETL), 2002, Process Equipment Cost Estimation: Final Report, Report No. DOE/NETL-2002/1169, Department of Energy, U.S.

Ordorica-Garcia, G., Douglas, P., Croiset, E. and Zheng, L., 2006, Technoeconomic evaluation of IGCC power plants for $\mathrm{CO}_{2}$ avoidance. Ener. Conv. Man., 47: 2250-2259.

Perry, R.H. and Green, D.W., (1997). Perry's Chemical Engineers' Handbook (7th edition). (McGraw-Hill).

Peters, M.S., Timmerhaus, K.D. and West, R.E., (2003). Plant Design and Economics for Chemical Engineers (5th edition). (McGraw-Hill).

Phillips, J., (2006). Different types of gasifiers and their integration with gas turbines. In The Gas Turbine Handbook, Chapter 1.2.1. (U.S. Department of Energy, Office of Fossil Energy, National Energy Technology Laboratory). DOE/NETL-2006-1230

Ponton, J.W. and Donaldson, R.A.B., 1974, A fast method for the synthesis of optimal heat exchanger networks. Chem. Eng. Sci., 29: 2375-2377.

Quinkertz, R., Ulma, A., Gobrecht, E. and Wechsung, M., 2008, Power-Gen Asia, Kuala Lumpur, Malaysia, 21-23 October,

Ratafia-Brown, J.A., Manfredo, L.M., Hoffmann, J.W., Ramezan, M. and Stiegel, G.J., 2002, An environmental assessment of IGCC power systems, In 19th Annual Pittsburgh Coal Conference Pittsburgh, 23-27 September,

Rubin, E.S., Chen, C. and Rao, A.B., 2007, Cost and performance of fossil fuel power plants with $\mathrm{CO}_{2}$ capture and storage. Ener. Pol., 35: 4444-4454.

Sadhukhan, J., Mustafa, M.A., Misailidis, N., Mateos-Salvador, F., Du, C. and Campbell, G.M., 2008, Value analysis tool for feasibility studies of biorefineries integrated with value added production. Chem. Eng. Sci., 63(2): 503-519.

Sadhukhan, J., Zhang, N. and Zhu, X.X., 2003, Value analysis of complex systems and industrial application to refineries. Ind. Eng. Chem. Res., 42(21): 5165-5181.

Shah, M., Raybold, T., Jamal, A., Drnevich, R., Bonaquist, D. (Praxair) and Jones, R. (GE Energy), 2005, IGCC: $\mathrm{CO}_{2}$ capture ready? Gasification Technology Conference, San Francisco, 9-12 October.

Shilling, N.Z. and Lee, D.T. (GE Energy), 2003, IGCC—clean power generation alternative for solid fuels, PowerGen Asia, Ho Chi Minh City, Vietnam, 23-25 September.

Simbeck, D. (SFA Pacific Inc.), 2005, SFA's Pacific's insights and overviews of lignite gasification, The New Zealand Lignite Symposium, Invercargill, New Zealand, 10 March.

Simbeck, D.R. and Chang, E., 2002, Hydrogen supply: cost estimate for hydrogen pathways-scoping analysis, Technical Report No. NREL/SR-540-32525, SFA Pacific, Inc., California. 
Sinnott, R.K., (2006). Coulson and Richardson's Chemical Engineering Series: Chemical Engineering Design (Elsevier Butterworth-Heinemann).

Smith, R., (2005). Chemical Process Design and Integration. John Wiley \& Sons Ltd).

Tobiesen, A. and Svendsen, H.F., 2005, Modeling the regeneration units for amine based $\mathrm{CO}_{2}$ absorption plants: introduction of an organic stripping medium, In 18th International Conference on Efficiency, Cost, Optimization, Simulation and Environmental Impact of Energy Systems Trondheim, Norway, 20-22 June,

Tsatsaronis, G., 1993, Thermoeconomic analysis and optimization of energy systems. Prog. Ener. Comb. Sci., 19: 227-257.
The University of Manchester, School of Chemical Engineering and Analytical Science, STAR Software.

Vlaswinkel, E.E., 1992, Energetic analysis and optimisation of an integrated coal gasification-combined cycle power plant. Fuel Proc. Tech., 32: 47-67.

Wagner, M.W. and Uhrig-Homburg, M., 2007, Futures price dynamics of $\mathrm{CO}_{2}$ emission certificates-an empirical analysis. http://ssrn.com/abstract=941167 (accessed 17 April 2009).

Williams, E., Greenglass, N. and Ryals, R., 2007, Carbon capture, pipeline and storage: a viable option for North Carolina Utilities. Report No. CCPP WP 07-01, Nicholas Institute for Environmental Policy Solutions and The Center on Global Change, Duke University. 